IZA DP No. 993

Total Factor Productivity Growth and J ob Turnover in Mexican

Manufacturing Plants in the 1990s

Angel Calderon-Madrid

Alexandru Voicu

J anuary 2004 


\title{
Total Factor Productivity Growth and Job Turnover in Mexican Manufacturing Plants in the 1990s
}

\author{
Angel Calderon-Madrid \\ El Colegio de México \\ Alexandru Voicu \\ IZA Bonn \\ Discussion Paper No. 993
January 2004
}

IZA

P.O. Box 7240

D-53072 Bonn

Germany

Tel.: +49-228-3894-0

Fax: +49-228-3894-210

Email: iza@iza.org

This Discussion Paper is issued within the framework of IZA's research area Labor Markets in Transition Countries. Any opinions expressed here are those of the author(s) and not those of the institute. Research disseminated by IZA may include views on policy, but the institute itself takes no institutional policy positions.

The Institute for the Study of Labor (IZA) in Bonn is a local and virtual international research center and a place of communication between science, politics and business. IZA is an independent, nonprofit limited liability company (Gesellschaft mit beschränkter Haftung) supported by Deutsche Post World Net. The center is associated with the University of Bonn and offers a stimulating research environment through its research networks, research support, and visitors and doctoral programs. IZA engages in (i) original and internationally competitive research in all fields of labor economics, (ii) development of policy concepts, and (iii) dissemination of research results and concepts to the interested public. The current research program deals with (1) mobility and flexibility of labor, (2) internationalization of labor markets, (3) welfare state and labor market, (4) labor markets in transition countries, (5) the future of labor, (6) evaluation of labor market policies and projects and (7) general labor economics.

IZA Discussion Papers often represent preliminary work and are circulated to encourage discussion. Citation of such a paper should account for its provisional character. A revised version may be available on the IZA website (www.iza.org) or directly from the author. 
IZA Discussion Paper No. 993

January 2004

\section{ABSTRACT}

\section{Total Factor Productivity Growth and Job Turnover in Mexican Manufacturing Plants in the 1990s*}

This paper analyzes the performance of Mexican manufacturing firms following trade liberalization within a very specific institutional setting: The North American Free-Trade Agreement (NAFTA). We compare plants' productivity growth and patterns of job creation and destruction across their relative degree of integration into foreign product markets, their access to technology, and behavior with respect to research and development. Our findings show that access to imported inputs is the more significant vehicle for productivity enhancing effects of trade openness. Investment in technology is, by far, most strongly correlated with plant productivity. Like productivity, job turnover at firm level is strongly influenced by the degree of integration in international markets, import competition, and R\&D behavior.

JEL Classification: C14, D24, F13, G63, O54

Keywords: total factor productivity, NAFTA, R\&D, job creation and destruction

Corresponding author:

Alexandru Voicu

IZA

P.O. Box 7240

53072 Bonn

Germany

Email: voicu@iza.org

\footnotetext{
* Suggestions and comments from Abigael Duran of the Mexican National Institute of Statistics, INEGI, in Aguascalientes, Mexico, were very useful in the elaboration of this paper. We are grateful to him, to Alex Cano, and to the staff of INEGI for making this research possible. The conclusions expressed here and remaining errors are exclusive responsibility of the authors.
} 


\section{Introduction}

The analysis of panel data sets of countries that have embarked in sweeping trade reforms over the past four decades has revealed a large degree of withinindustry plant heterogeneity in ..rm responses ${ }^{1}$. In view of this fact, a consensus has been emerging that aggregate models with representative ..rms are ill suited for understanding the exects of trade liberal ization on the productivity and employment of manufacturing industries. R ecent empirical research has focused on testable hypotheses derived from dynamic models that link trade regimes with theoretical insights from industrial evolution literature and explicitly consider .rm heterogeneity.

The hypothesis that attracted most attention in the analysis of developing countries concerns the positive exect of import competition on the productivity of domestic ..rms. Competition from foreign ..rms induces a disciplining exect among domestic producers. Hence import tarixs on ..nal products should be negatively correlated with domestic ..rms' total factor productivity. A nother possible explanation for the relationship between import tarixs and productivity, which received far less attention, is that tarix reductions enhance ..rms' productivity by allowing better combinations of domestic and imported intermediate in puts ${ }^{2}$.

In addition to the prevalence given to the former channel at the expense of the latter, existing studies implicitly assume that liberalization of trade takes place in institutional contexts in which credibility problems do not exist, or that incentives to invest and become more productive do not depend on the credibility of the trade regime. Lack of credibility of the commitment to irreversible trade reforms is functionally equivalent to a distortion in the structure of intertemporal relative prices (Calvo, 1986). Economic agents base their actions on prices which dixer from those that will materialize if the reform is carried out to fruition. This distortion creates a second-best environment (Rodrik, 1989). B ecause this insight has not permeated empirically oriented papers, there is no mention on how their results and estimation procedures would be axected by a lack of a credible commitment for ir rever sibility of trade liberalization ${ }^{3}$.

\footnotetext{
1IDB, 2003 for M exico and Brazil; Levinsohn and Petrin, 1999, Pavcnik, 2002 and Bergoeing et al., 2003 for Chile; Medina et. al (2002) for Colombia; Haddad, 1993 for M arroco and $\mathrm{P}$ ravina and $\mathrm{M}$ iltra 1997 for India.

${ }^{2}$ A study by Bernard et. al. (2002) considers a fall in trade costs, which comprise tari as paid on importing intermediate goods, as a positive channel for productivity improvements in A merican ...rms. By contrast, Lopez-Cordova and M esquita Moreira (2002) reject the hypothesis that in Brazil and Mexico expanded use of imported inputs have no impact of total factor productivity of domestic plant and a negative impact on for eign ..rms operating in these count ries.

${ }^{3}$ T he probl ems associated with it have been well establish ed in theoretical papers. Levinson (1986) proposes a model in which the large degree of within industry heterogeneity increases uncertainty about the distribution of gains from trade reform, rendering the support for reforms weak. R odrik (1989) develops a model in which this may occurr because of incomplete or asymetric information. The idea that a government that mantains policy discretion might be tempted to use trade instruments follows from the time inconsistency argument. Finally, a similar argument has been advanced to explain why temporary infant industry protection may not lead to expected ec ciency changes.
} 
The absence of this insight is more conspicuous when liberalization of trade is accompanied by trade agreements with other countries. In these cases a transition from a partially credible to a credible commercial regime can be an important explanatory factor for observed changes in productivity and job turnover in manufacturing ..rms. The North A merican Fre Trade A greement (NAFTA) is an archetypical case in which this transition took place. The agreement provided for a phase-out of trade tarias over a period of 10 to 15 years, a stable and transparent legal environment for foreign investors, a broader protection of trademarks and patents, as well as other measures to facilitate access to foreign technology. In addition, NAFTA provided Mexican manufacturers an unprecedented degree of predictability of trade tarims and insured rule-bound behavior in Mexican, USA, and Canadian trade policy.

This paper uses plant-level panel data to analyze the performance of manufacturing ..rms between 1993-2000. The data set combines information from three sources: A nnual Industrial Survey (AIS), Industrial Census (IC), and $\mathrm{Na}$ tional Survey of Employment, Salaries, Technology and Training (ENESTYC). We seek to shed light on two key issues. Tarix reduction leads to performance improvements through two channels: better access to a larger menu of imported inputs and stronger import competition on domestic markets. The main goal of the empirical analysis is to assess the importance of these two channels in the case of Mexican manufacturing ..rms.

NAFTA meant a stable and transparent legal environment for foreign investors, a broader protection of trademarks and patents, as well as other measures to facilitate access to foreign technology. For a better understanding of the determinants of plant performance, we analyze the relationship between performance and variables describing access to technology. The two variables considered were expenditures in $R \& D$ and technology transfer, and the relative importance of alternative sources of technological transfers.

Throughout, we focus on two aspects of ..rm performance, total factor productivity (henceforth, productivity) and job turnover. F irm performance is analyzed at several levels. We construct productivity estimates and job turnover rates for the entire manufacturing sector and, separately, for 2-digit SIC industries. Our empirical strategy is to compare performance across plant characteristics intrinsically related to components of the free trade agreement.

We ..nd that most productivity gains at industry level are achieved through reshu- ing of resources from less to more productive ..rms. Our ..ndings underscore the importance of better access to imported inputs as a channel for productivity enhancement exects of taria reductions. F irms using larger shares of imported inputs show stronger productivity growth. Better access to imported inputs has a stronger positive exect of productivity for ..rms exporting larger shares of output. We ..nd no signi..cant exect of import competition on productivity. Investments in technology are a strong determinant of ..rm productivity. J ob reallocation patterns dixer signi..cantly across years with high/low(or normal) turnover. There are no signi..cant performance dixerences across integration, import competition, and investments in technology in low turnover year. In high turnover years, integration and expenditures in tech- 
nology have a positive impact on ..rms performance, while import competition axects negatively ..rms' prospects.

The remainder of this paper is organized as follows. In section 2 we discuss the free-trade agreement and its implications for the Mexican manufacturing ..rms, and review some of the relevant literature. In section 3 we present our empirical strategy. Section 4 contains a detailed description of the data sources used in this paper. In section 5 we describe the technique used for estimating the production functions and discuss the estimation results. The empirical analysis of the exect of trade liberalization on productivity and employment patterns is presented in section 6 , followed by concluding remarks and a review of the goals of future research. 


\section{Background}

By J anuary 1994, when manufacturers started to perform within NAFTA's framework, M exico had al ready been transformed from an inward-looking economy into a largely open economy. As part of its accession to the G ATT in 1986, $M$ exico had substantially reduced and rationalized its import tarix $\mathrm{s}^{4}$. The economy was largely reliant on private enterprise after privatization, deregulation, and other major economic reforms undertaken after 1985.

Negotiations towards establishing NAFTA began in 1990 and the accord was signed in December 1992. NAFTA was an institutional setting designed to promote foreign investment and enhance ec ciency in manufacturing sectors. It contained provisions which facilitated the cross-border integration of industries in North America. The most important provisions concerned tariæ phase-out. A general principle of a ten-year maximum for tarix phase-outs was adopted; ...fteen-year phase-out schedules were agreed for exceptional cases. Four main staging tarix phase-out categories, A-D, and two special cases categories, B + (most textile tariæs) and B8- (four tarix items in the paper sector) were speci..ed $(\text { table } 1)^{5}$. Tarix reduction schedules became publicly available one year before the start of NAFTA. For each product, they speci..ed a phase-out category and the 1991 tarix, chosen as base level.

By the time NAFTA took exect, M exican import tarixs of non-agricultural goods have been substantially reduced from their high levels in 1985. As shown in the following table, the treaty involved a relatively low degree of tarix liberalization, because trade $\ddagger$ ows between $C$ anada, M exico and the United States were already relatively free.

Additional provisions were aimed at establishing a stable and transparent legal environment for foreign investors, a broader protection of trademarks and patents, as well as other measures to facilitate access to foreign technology. The treaty did not cover domestic microeconomic reforms such as privatization or deregulation. Implicitly, however, the treaty signaled to foreign investors that domestic reforms will continue and that Mexico's private sector was in good health (Fernandez and Portes, 1998).

A rguably, the most important character istic of the free-trade agreement was the un precedented level of predictability lent to M exican, U.S.A . and Canadian trade policy. The signing of NAFTA ensured that the openning of Mexican economy to foreign competition was irreversible. All relevant information regarding phasing out of tarixs was available to private agents one year before the start of NAFTA. Ruling out the discretionary use of trade instruments, unlike previous announcements of tario removal, NAFTA enjoyed full credibility.

\footnotetext{
${ }^{4}$ In 1985 , over $90 \%$ of domestic production was covered by import licences and the average exective tarix protection rate was $30.7 \%$; in 1990, only $11.20 \%$ of domestic production was covered and the average tearix rate was $8.57 \%$ (Tybout and Westbrook, 1995).

${ }^{5}$ A bout $54 \%$ of U.S. imports from M exico were bound to be free on implementation of the Treaty (category A), $8.5 \%$ within 5 years (category B), 23\% within 10 years (category C) with about $14 \%$ of imports already being duty free before NAFTA. For M exican imports the corresponding estimates were $31 \%$ in category $A, 17 \%$ in category $B, 32 \%$ in category $C$, and $8 \%$ in itially free (K owal czyk and Davis, 1996).
} 
We expect multiple exects of NAFTA provisions on domestic plants. M anufacturers trying to match their input mix more precisely to a desired technology or product characteristics, were insured low import tarixs and unfettered access to a large menu of imported intermediate goods. F irms with exporting potential, considering e\& ciency enhancing investments, were reassured that U.S. and Canadian import tarias will stay low and contingent protection will not be imposed by these countries. Ruling out the discretionary use of trade instruments was an important element of uncertainty reduction, in view of the major balance of payments crisis that occurred in December 1994 and given memories of previous episodes when balance of payment problems triggered across the board import restrictions $s^{6}$. For import competing ..rms with a temporarily protected local market, the irreversibility of an open trade regime and the credibility of pre-announced phasing-out of remaining trade tarixs implied an unambiguous message: this was de..nitively their last "breathing space" to become internationally competitive.

A cursory analysis of the aggregate performance of the manufacturing sector after 1993 indicates that NAFTA might have, indeed, played a signi..cant role. At the end of 1994, manufacturers were exposed to severe macroeconomic shocks. Real exchange rate depreciated in D ecember 1994 by more than $40 \%$. A ..nancial crisis and a severe domestic economic recession followed in 1995. The manufacturing sector was driven out of this recession by an un precedented good performance of exporting ..rms. Mexican exporters took advantage of the unpreced ented expansion of U.S. market between 1995 and 1998, and of the temporarily undervalued domestic currency. Table 1 shows that during this period $M$ exican manufactures increased their market share, reaching a new plateau of participation in U.S. markets by 1998.

The main goal of this paper is to provide a detailed analysis of the performance of Mexican manufacturing ..rms between 1993 and 2000. We construct estimates of individual plants productivity and investigate the relationship between trade reforms and plant performance. A ssessing the relationship between reductions in import tarixs and changes in ec ciency is problematic for two reasons. In general, the relationship cannot be cannot be automatically interpreted as causal. Tarix rates may be set endogenously in response to changes in ef...ciency. In the case of NAFTA, however, this problem does not exist. Tarix levels after 1994 are truly exogenous, as their levels for the ent ire period are unaxected by changes in productivity (Lopez-Cordova, 2002). Secondly, even if the relationship can be given a causal interpretation, quantifying it remains problematic. A djustments of trade tarias between 1994 and 2000 were announced in advance and enjoyed credibility. Unless ..rms behaved myopically, it is reasonable to assume that their reactions to the change in trade regime do not strictly

\footnotetext{
${ }^{6} \mathrm{~T}$ his can be contrasted, with the Chilean trade liberalization experience during the eighties and the Colombian one in the nineties. These studies implicitly assumed a context in which a commitment to free trade per sisted -and was believed by the private sector to be so. This assumption is does not appear to have held all the time. For example, Pavnik (2002), referred that there was "a transitory period of increased tari protection starting in 1983 in response to the $1982-83$ recession".
} 
match these changes time wise. M ost likely, ..rms responded to expected future tari reductions rather than to realized new levels of tarias.

In view of the dic culties involved in dealing with 'import discipline exect' in this way, we take an alternative route in this paper. We rely instead on a cross section survey that was applied to the majority of ..rms for which we calculate yearly changes in total factor productivity. In what turned out to be an extremely timely point in time for the purposes of this analysis - second quarter of 1995 - a survey registered their qualitative perception of the most important exect of foreign trade liberalization policies on their plants.

$W$ ith the information provided by this survey we classi...ed the set of ..rms in four groups, according to their own assessment. Respondents could choose one out of four possible answers, which were: 'an increase in foreign competition in their domestic markets', 'no exect at all', 'more facility to export' and 'access to new and/ or better technologies'7. T his r oute has the disad vantage that we cann ot identify productivity changes that were registered in 1993 - the year capturing the exects on ..rms of the 'arrival of news of the import liberalization program'. B y contrast, it can allow us to assess the robustness of results suggesting that M exican plants experienced an important 'import discipline exect' during the years 1994-2000.

\subsection{Previous studies of the exects of trade liberalization in M exico that used industry panel data sets}

Tybout and Westbrook (1995) use the 1984-1990 sample of the Annual Industrial Survey (AIS), to study the performance of Mexican ..rms. They decompose productivity changes into exects of plant-level scal e econ omy exploitation, movements of individual plant s toward the production frontier, and shifts of that production frontier due to innovation, externalities, and other forces. They found only mild increasing returns to scale. W ith few exceptions the largest ..rms had al ready reached a minimum eф cient scale. The association between openness and ...rms productivity were weak ${ }^{8}$. Exporting ...rms experience only small ef...ciency gains from the opening up of the economy but bene.ted from lower import prices and better terms of trade. Trade openness - measured by import penetration or changes in o\$ cial tario rates - worsened the scale e\$ ciency of import competing ..rms.

\footnotetext{
${ }^{7}$ Forty four percent of ...rms in our sample responded in the third term of 1994 having to compete more intensively with foreign ..rms as the exect of trade liberalization so far undertaken. When they answered this question, NAF TA had already gone into exect along with the most relevant tarix adjustments associated to it.

${ }^{8} \mathrm{~T}$ hese authors had dic culties in ident ifying trade policy measures to analyze the relative openness of the various industries. They found 'surprisingly little association' among the alt ernative measures of trade exposure, among these, change in exective protection rates, change in licen ce cover age rati os and change in o\$ cial import tarix rates; all of them measured as the dix erence between 1990 and 1984 ..gures. They also found that non of them correlated closely with import penetration.
} 
T wo recent reports, by the World B ank and the Inter-A merican Development $B$ ank, respectively, have analyze ..rms' performance during NAFTA's years using Mexico's A nnual Industrial Survey (AIS). As we do in this study, they followed three steps. The ..rst one, estimate production functions for the main manufacturing sectors using plant level data. Then, with the discrepancy between forecasted and actual values of output, obtain plant level total factor productivity. Finally, assess the extent to which estimates of total factor productivity changes are statistically related to a potentially explanatory variables. ${ }^{9}$.

IDB (2002) implications about the performance of exporters do not dixer from those of Tybout and Westbrook. The hypothesis that exporting plants had higher rates of total factor productivity growth than non-exporting ones is rejected. No correlation between export to sales ratio and total factor productivity growth was found at plant level ${ }^{10}$.

B y contrast, ..ndings unambigously supported the import discipline hypothesis. Stronger competition from foreign goods had a positive impact on productivity. The 10 point reduction in tarixs between 1993-1999 raised productivity by roughly 4 percentage points. The one percent increase in import output ratio raised productivity by an additional quarter of percentage point. They look for evidence that could suggest that an expanded use of imported inputs favored productivity improvements. For the case of domestic ..rms they concluded that using imported inputs does not axect total factor productivity growth; for the case of foreign ..rms, that imported inputs have an adverse impact on productivity growth.

The W orld B ank team uses the AIS and ENESTY C survey to estimated plant productivity between 1993-1997. The study assesses the extent to which productivity gains from export ing have been realized through learning by direct exporters or through spillover to indirect exporters and others.

\subsection{Studies in Latin A merica with industry panel data sets and non-parametric techniques}

The Chilean experience of the 1970's has become an arhetipical example to study the exects of total factor productivity changes induced by liberalization of trade regime. T wo studies, P avnick (2002) and Levinshon and P etrin (1999), have analyzed this period. In a recent paper, Bergoeing et. al. (2003) ex-

\footnotetext{
${ }^{9} \mathrm{~T}$ here are at least three reasons for dixerences in their total factor productivity results and the ones presented in next section. First and most importantly, each study uses a dixerent method to correct for biases in the estimation of the production function; second, our study corrects for measurement problems in capital stock to conform with economic concepts, these studies rely on accounting values for initial values of capital stock and for their depreciation rates, do not correct for imputed values of rented buildings or sales of assets during a year. F inally, sample sizes may dixer, the World Bank study stops at 1997 and the IDB report uses investment as an instrumental variable. B ecause of this, it is forced to leave out of their estimation those ..rms with a year without investing.

${ }^{10}$ They found, however that an increase in favor of Mexican goods in the U.S. market is positive associated with an increase in productivity.
} 
tended the period to include the 1990's. In addition to a larger horizon of study they developed the following methodological point. Estimating of total factor productivity requires correcting for the sources of bias in the coet cients of a production function. O ne of them has as a source the determinants of decision to exit the market. A ccording to these authors, estimation of ..rms exit decisions require including as their determinant not only stock of capital -as it is usually done when the Olley Pakes method is used. Changes in taxes, if they axect ..rm's decisions must also be included ${ }^{11}$. By the same reasoning, other variables reł ecting distortionary policies, such as barriers to foreign trade, that axect the development of speci..c sectors should also be incorporated among the determinants of ..rm's survival.

\footnotetext{
${ }^{11}$ This methodological point is also in Medina et. al. 2002, for a study of Productivity Dynamics of the Colombian Manufacturing Sector.
} 


\section{Empirical strategy}

We seek to shed light on two key issues. Tarix reduction leads to performance improvements through two channels: better access to a larger menu of imported inputs and stronger import competition on domestic markets. The main goal of the empirical analysis is to assess the importance of these two channels in the case of Mexican manufacturing ..rms.

NAFTA meant a stable and transparent legal environment for foreign investors, a broader protection of trademarks and patents, as well as other measures to facilitate access to foreign technology. For a better understanding of the determinants of plant performance, we analyze the relationship between performance and variables describing access to technology. The two variables consider ed were expenditures in $R \& D$ and technology transfer, and the relative importance of alternative sources of technological transfers.

Throughout, we focus on two aspects of ..rm performance, total factor productivity (henceforth, productivity) and job turnover. F irm performance is analyzed at several levels. We construct productivity estimates and job turnover rates for the entire manufacturing sector and, separately, for 2-digit SIC industries. Our empirical strategy is to compare performance across plant characteristics intrinsically related to components of the free trade agreement.

W e begin by est imating the replacement value of capital st ock, combining information from the Industrial Census and A nnual Industrial Survey. Production functions are estimated at two-digit SIC level, using a semiparametric, which we present in detail in the next section. Productivity measures are constructed using production function estimates. The second dimension of plant performance - job reallocation rates - are computed at plant level. The joint study of productivity and job reallocation of M exican ...rms has not been yet attempted. O ur goal is to document the relationship between these two dimensions of plant performance.

The main part of our empirical analysis contains the analysis of plant performance across three sets of plant characteristics: degree of integration into international markets, relative strength of import competition faced, and investments in technology. The role of import competition has been extensively studied, with mixed results. O ur goal in this paper is, however, broader. Not only do we evaluate the exect of import competition and trade integration on plant performance, but we try to shed light on the relative importance of import competition and better access to imported inputs as channels for performance enhancement exects of trade liberalization. The relationship betwen performance and invest ments in technology, to our knowledge, has not been analyzed in the case of M exico. We analyze this relationship using two dixerent measures of behavior towards $R \& D$. F irst, we use actual amounts spent on $R \& D$ and technology acquisitions. Second, we use ..rms perceptions to infer how NAFTA provisions (broader protection of trademarks and patents, etc.) have axected productivity. 


\section{Data}

T his paper uses data from three main sources: Annual Industrial Survey (AIS), Industrial Census (IC), and National Survey of Employment, Salaries, Technology and Training (ENESTYC). The National Institute of Statistics and Geography, INEGI, that gathers and processes these data, allowed us to work with them on their premises, in the City of A guascalientes.

The initial year of our analysis is 1993. This choice has several advantages. The IC, which takes place every ..ve years, was conducted in 1993. U sing the 1993 C ensus as universe, a new sample was selected for AIS. T he new sample has al most double the size of the 1984-1992 A IS sample. In addition, being based on the IC, is statistically represent ative for the manufacturing sector in 1993. The 1998 IC did not give place to a new sample of plants for the AIS. No plant was excluded or included to adjust the AIS sample to the universe provided by the new Census. Although this might have updated the statistical representativity of the industrial sector, in terms of the continuity of the panel, it represented an additional advantage. T hanks to the car eful follow-up of plants by personnel of the INEGI, ..rms included in the sample because of initiation of operations and those excluded because of bankruptcy are well identi..ed in this data set. A set of identi..ers allows us to match AIS plants with both 1993 and 1998 IC.

The capital stock and a detailed estimation of depreciation rates for each of its components were obtain ed from the Industrial C ensus conducted in 1993 and 1998. The questions in the IC for capital stock and depreciation rates refer to the cost of reposition or market price of the stock of capital. Firms are asked to consider reevaluations due to exchange rate variations and, most importantly, to deduct for physical deterioration and its obsolescence. Investment expenditures from the AIS were then used to calculate capital stocks at replacement cost values for every year using a perpetual inventory method. Price deł at ors for capital stock, buildings, rents and el ectricity were obtained from Banco of M exico's data bases. Firms in AIS are grouped in 205 classes. INE GI generates a price index for each of them. We employed this price index to dełate value added.

ENESTY C surveys- Encuesta nacional de Empleo, Salarios, Tecnología y Capacitacion were conducted in 1995 and 1999. T hey were designed to measure the impact of opening the economy and modernization on employment. From this survey, we use information on two aspects of the plant's activity: the exect of the freetrade agreement and the source of technology.

The structure of the panel data set with is presented in the table 3. 


\section{Production function estimation}

T wo problems must be addressed in estimating production functions with panel data sets. First, the correlation between in put levels and unobserved productivity shocks induces simultaneity bias in the OLS estimation. Second, ..rms with low realizations of productivity exit the market. If ..rms with larger capital stock are more likely to survive negative realizations of productivity shocks, the O LS estimat or of the capital coet cient will be biased.

Several ways of dealing with these problems have been used in the liter ature. Olley and Pakes (1996) proposed a technique that allows corrections for both the selection bias introduced by non-random exits and the simultaneity bias. Firm's invest ment function is modeled as a function of capital and productivity level - unobserved to the econometrician. Under certain conditions, the investment function can be inverted, thus providing an instrument for the unobserved productivity component. The selection bias is corrected by formally modeling ..rm's survival decision and incorporating it into the estimation.

L evinsohn and Petrin (2001) have proposed an approach which requires less strict assumptions than those imposed on the investment function in $\mathrm{Olley}$ and Pakes. They argue that investment responds only to the non-forecastable component of the productivity shocks. As a result it does not perform well if the productivity term has both a serially correlated component and an idiosyncratic component. Instead, ..rm's intermediate input demand is used to obtain an instrument for the unobserved productivity shock.

A number of recent papers have used this idea and employed a modi..ed version of the initial Olley and Pakes approach in which the investment function was replaced by the intermediate in put demand. Electricity provides the best instrument since few ..rms produce it and it cannot be stored. In this paper we use this later approach.

Consider the production function of ..rm at time t:

$$
y_{i t}=\alpha+\beta_{s} l_{i t}^{s}+\beta_{u} l_{i t}^{u}+\beta_{k} k_{i t}+\omega_{i t}+\varepsilon_{i t}
$$

where $y_{i t}$ is log value added, $l_{i t}^{s}$ is log of skilled labor, $l_{i t}^{u}$ is log of unskilled labor, $k_{i t}$ is log of plant's capital stock, $\omega_{i t}$ is the level of plant speci..c productivity, and $\varepsilon_{i t}$ is white noise A ..rm's private knowledge of $\omega_{i t}$ plays a role in both exit and input choice decisions. Firm's demand for electricity is:

$$
e_{i t}=e_{i t}\left(\omega_{i t}, k_{i t}\right)
$$

Under monotonicity conditions, the demand function can be inverted,

$$
\omega_{i t}=\omega_{i t}\left(e_{i t}, k_{i t}\right)
$$

Replacing $\omega_{i t}$, (1) becomes:

$$
y_{i t}=\beta_{s} l_{i t}^{s}+\beta_{u} l_{i t}^{u}+\phi\left(e_{i t}, k_{i t}\right)+\varepsilon_{i t}
$$


where $\phi\left(e_{i t}, k_{i t}\right)=\alpha+\beta_{k} k_{i t}+\omega_{i t}$

In the ..rst step we use OLS to estimate $\hat{\beta}_{s}$ and $\hat{\beta}_{u}$ in (2) where $\phi\left(e_{i t}, k_{i t}\right)$ is represented by a polynomial expansion in $e_{i t}$ and $k_{i t}$. Using the coec cient estimates at the ..rst step, we calculate an estimate for $\phi\left(e_{i t}, k_{i t}\right), \hat{\phi}\left(e_{i t}, k_{i t}\right)=$ $y_{i t}$ i $\hat{\beta}_{s} l_{i t}^{s}$ i $\hat{\beta}_{u} l_{i t}^{u}$

Let

$$
y_{i t+1}^{\mathrm{d}}=y_{i t+1} \mathrm{i} \quad \beta_{s} l_{i t+1}^{s} \mathrm{i} \quad \beta_{u} l_{i t+1}^{u}=\alpha+\beta_{k} k_{i t+1}+\omega_{i t+1}+\varepsilon_{i t+1}
$$

To address the selection bias problem, ..rm's exit decision is speci..cally modelled. Writing the realization of the new productivity shock as a sum of a forecasted component and an idiosyncrat ic component, $\omega_{i t+1}=E\left[\omega_{i t+1} \mathrm{j} \omega_{i t}\right]+$ $\eta_{i t+1}$, and denoting $g\left(\omega_{i t}\right)=\alpha+E\left[\omega_{i t+1} \mathrm{j} \omega_{i t}\right]$, (3) becomes

$$
y_{i t+1}^{\mathfrak{a}}=\beta_{k} k_{i t+1}+g\left(\omega_{i t}\right)+\varepsilon_{i t+1}
$$

A .rrm is observed only if the realization of productivity is above a certain threshold. The ..rms exit decision is then represented by:

$$
\begin{aligned}
& X_{t}=1 \text { if } \omega_{t}>\underline{\omega_{t}} \\
& X_{t}=0 \text { otherwise }
\end{aligned}
$$

Incorporating the exit decision, (3) becomes:

$$
\begin{aligned}
y_{i t+1}^{\alpha} & =y_{i t+1} \mathbf{i} \beta_{s} l_{i t+1}^{s} \mathbf{i} \beta_{u} l_{i t+1}^{u}= \\
& =\alpha+\beta_{k} k_{i t+1}+E \omega_{i t+1} \mathbf{j} \omega_{i t}, \omega_{t+1}>\underline{\omega_{t+1}}+\eta_{i t+1}+\varepsilon_{i t+1}
\end{aligned}
$$

The second estimation step is then:

$$
\begin{aligned}
y_{i t+1}^{\mathrm{d}}=y_{i t+1} \mathrm{i} & \hat{\beta}_{s} l_{i t+1}^{s} \mathrm{i} \hat{\beta}_{u} l_{i t+\mathrm{\jmath}}^{u}= \\
= & \beta_{k} k_{i t+1}+g \hat{\phi}\left(e_{i t}, k_{i t}\right) \mathrm{i} \beta_{k} k_{i t}, \hat{P}_{i t}^{\prime}+\eta_{i t+1}+\varepsilon_{i t+1}
\end{aligned}
$$

$\mathrm{W}_{3}$ e use a polynomial expansion for $g_{1_{3}}$

$g \hat{\phi}\left(e_{i t}, k_{i t}\right)$ i $\beta_{k} k_{i t}, \hat{P}_{i t}={ }_{j}{ }_{l}^{\mathrm{P}} \beta_{j l} \hat{\phi}\left(e_{i t}, k_{i t}\right)$ i $\beta_{k} k_{i t}{ }^{j} \hat{P}_{i t}^{l}$ and non-linear least square to estimate (4).

F inally, using the coec cient estimates from the two steps, we calculate total factor productivity as

$$
\hat{\omega}_{i t}=y_{i t} \mathbf{i} \hat{\beta}_{s} l_{i t}^{s} \mathbf{i} \hat{\beta}_{u} l_{i t}^{u} \mathbf{i} \hat{\beta}_{k} k_{i t}
$$

Production functions are estimated separately for eight two-digit SIC manufacturing industries: food processing textiles and appare, manufacture of wood 
products, manufacture of paper and paper products, chemical industry, glass, basic metals, and manufacturing of machinery and equipment. We compare coeф cient estimates for three alternative speci..cations: ..xed exects estimation of both the balanced panel and the full data set (tables 4 and 5), and the semiparametric estimation of the full data set (table 6). The ..xed-exect estimates are similar for the balanced panel and the full-data set. The main reason for this is the small number of ..rms exiting. Findings are consistent with the predictions about the signs of the biases.

For all sectors, semiparametric estimation yields higher coet cients of capital and skilled labor, and lower coec cients of unskilled labor. This ..nding is consistent with the predictions regarding simultaneity bias: the use of easily adjustable factors, like unskilled labor, is positively correlated with productivity shocks, inducing upward biased of ..xed exect estimates. The reverse is true for factors which are slow to adjust like skilled labor. Higher capital coeł cients are consistent with the prediction that large ..rms have a better chance to survive adverse productivity shocks.

A further indication that the semiparametric estimation provides superior results in given in table 7 . We use the estimated coed cients to cal culate marginal product of capital and the ratio of the marginal products of unskilled and skilled labor. Fixed exect estimates yield counterintuitive higher marginal product for unskilled workers for six of the eight sectors, while the semiparametric approach delivers reasonable marginal product estimates for the two categories of labor.

F inally, four of the nine sectors display incr easing returns to scale when using the semiparametric approach. No sector is characterized by increasing returns to scale if the ..xed exect estimates are used. 


\section{Results}

\subsection{M anufacturing: productivity and job reallocation}

Using coec cient estimates from the semiparametric estimation, we construct a measure of plant productivity. The productivity index (used, among others by Pavcnik, 2002) measures the distance from average industry practice in a base year for each plant. Formally, let $p r_{i t}$ be the value of the productivity index of plant $i$ in period $t$. Then,

$$
p r_{i t}=y_{i t} \mathbf{i} \hat{\beta}_{s} l_{i t}^{s} \mathbf{i} \hat{\beta}_{u} l_{i t}^{u} \mathbf{i} \hat{\beta}_{k} k_{i t} \mathbf{i}\left(y_{r} \mathbf{i} \hat{y}_{r}\right)
$$

where $y_{r}=y_{i t}$ and $\hat{y}_{r}=\hat{\beta}_{s} t_{i t}^{s} \mathbf{i} \hat{\beta}_{u} t_{i t}^{u} \mathbf{i} \hat{\beta}_{k} k_{i t}$

Productivity gains at industry level can be realized either through productivity gains at plant level or through reshu- ing of resources from less productive to more productive ..rms. We compute the measure of aggregate industry productivity $W_{t}$ as a weighted average of individual productivity levels. Weights $s_{i t}$ are given by value added share in total industry value added in a particular year. The aggregate productivity measure is decomposed in two components. The unweighted productivity measure $\overline{p r}_{t}$ measures product ivity gains at plant level while the covariance between plants' value added share and productivity gives a measure of industry productivity gains through resource reshu- ing.

$$
W_{t}={ }_{i}^{\mathrm{X}} s_{i t} p r_{i t}=\overline{p r}_{t}+{ }_{i}^{\mathrm{X}}\left(s_{i t} \mathbf{i} \xi_{t}\right)\left(p r_{i t} \mathbf{i} \overline{p r}_{t}\right)
$$

T able 8 shows the result s of the decomposition. P roduct ivity ind ex measures deviations from mean industry productivity in 1993, the ...rst year of the panel. Values in the table are normalized by subtracting corresponding 1993 levels. B etween 1993 and 2000 all industries realize important aggregate productivity gains. Glass, basic metals, and manufacturing of machinery, and equipment are the fastest growing industries. Reshu- ing of resources from less productive to more productive ..rms is the dominant mechanism for industry productivity gains. W ith the exception of basic metals, the covariance component exceeds the unweighted productivity component for all industries. The crisis of 1995 is clearly marked by sharp drops in unweighted productivity measures and more intense reallocation of resources. The rates of job reallocation, shown in table 12 paint a similar picture. Year 1995 is characterized by large job destruction rates across sectors, while during 1996 most sector rebounded displaying high job creation rates. J ust as in the case of productivity, employment reallocation rates were much higher during these years pointing towards an intense process of resource reallocation. B esides the importance of resource reallocation as source of performance improvement, these result s underscore the importance of analyzing jointly productivity and job reallocation at plant level. 


\subsection{Reduction of tarias: better input mix or import com- petition}

Have reduction in tarixs and the implied international openness of economy axected plants' productivity? We analyze ...rm performance across two dimensions of market openness. First, we how the degre of integration in international markets axect performance. The degree of int egration is measured using plants' export performance and their relative share of imported intermediary inputs. We de..ne three categories of export performance - no exports, export less than 20 percent of sales, and export mor e than 20 percent of sales - and two categories of usage of imported inputs - import less than 20 percent of inputs and import 20 percent or more. In the regression analysis we use the six categories resulting from the interaction of export performance and use of imported inputs. Table 9 shows the results of a regression of productivity index on a quartic in from size, year dummies, dummy variables for the degree of integration in international markets, and interaction exects of year and degree of integration. Figure $1 \mathrm{com}$ pares plant productivity for all years across our measure of degree of integration in international markets. The main feature is the superior performance of ..rms using a large share of imported inputs. For all years and all categories of export performance, larger shares of imported inputs are associated with higher productivity. The dixerence becomes stronger over time, as ..rms using a larger menu of imported inputs display more robust growth patterns. Large exporters using a large share of imported inputs (exp2imp2) have the strongest productivity growth. Firms selling exclusively on the domestic market and using small quantities of imported inputs (exp0imp1) were worst hit by the 1995 crises. At the same time, the downturn in the US economy during late 1990's had a stronger exect on large exporters with low imported inputs use (exp2imp1).

Reduced tarixs stixen import competition and may have a disciplining, productivity-enhancing exect on domestic plants. We use ..rms perceptions about the exects of NAFTA to de.ne a measure of import competition at 4 digit SIC level. A sector is categorized as import competing if more than 38 percent (median level) of the ..rms considered import competition to be the strongest exect of NAFTA. Table 10 shows estimates of a regression of productivity on the level of import competition. As before, we control for plant size and include year dummies and inter action exects. F igure 2 shows the estimated productivity levels. We could ..nd no signi...cant exect of import competition on ..rm productivity.

O ur ..ndings underscore the importance of better access to imported inputs as a channel for productivity enhancement exects of tari reductions.

Tables 9 and 10 show results for regressions of gross job reallocation rate and rate of net employment change, respectively, on the same right hand side variables - measure of plant size, and variables describing the degree of integration into international markets and the level of import competition. Figures 3 to 6 plot the estimated turnover rates. Y ear 1995 to 1997 are characterized by high turnover rates. In 1995 they were driven by large job destruction an in the subsequent years by high job creation rates. During the rest of the period 
turnover rates were at normal levels, 10-15\%. Plant behavior with respect to these two dimensions of performance is dixerent across periods with high and normal turnover. Degree of integration has no signi..cant exect during normal turnover years. Exporting ..rms and those using larger shares of imported inputs perform better during high turnover years. Plants in import competing sect ors appear to be more "under the weather" as far as job turnover rates are concerned. They display higher rates of gross job reallocation in more turbulent years. rates of net employment change are more extreme for import competing plants. They tend to destroy more jobs in years with negative overall job change and to create more jobs in years with employment growth.

\subsection{Investment in technology}

Recent empirical studies suggest that adoption of technology may be far from automatic. Griф th et. al. (2000), for example, highlight that investments in research an development help ..rms achieve an "absorptive capacity" which facilitates technology adoption. This argument suggest that productivity growth is related to expenditures in research and development in technology, as well as to other variables directly rełecting a degree of access to foreign technology.

We use estimated productivity index to study the relationship between investments in $R \& D$ and productivity. Plants are classi..ed in three categories according to the annual amount allocated to $R \& D$ and transfer of technology: zero expenditures (noinv), positive amount but below $5 \%$ of yearly sales (invsm), and those with expenditures above $5 \%$ (invlrg). Table 11 shows the results of the regression of productivity index on a quartic in plant size, year dummies, dummy variables for categories of investment in $R \& D$, and interactions between year and investment categories. F igure 2 compares estimated productivity levels for every year across levels of investment in $R \& D$. Regression results show a clear positive exect of investments in technology. Firms that invest in $R \& D$ are, at all times, more productive than ..rms that do not invest and display faster growth. Figure 2 shows an even sharper picture. $N$ ot only investments in $R \& D$ are raising productivity, but the amount invested signi..cantly determines the rate of growth. If in 1993 ..rms with small and large investments were not signi..cantly dixerent, by 1997, the higher rate of growth made large investors signi..cantly more productive - dixerence which persisted until 2000. It is interesting to note that ..rms which invest more in $R \& D$ performed better during the 1995 crisis and showed no productivity decline in 2000.

J ob turnover rates are also signi..cantly dixerent across levels of investment in technology. During years with high turnover rates, 1994 to 1998, ..rms which make no investments experience higher rates of gross job reallocation and lower rates on net employment change. $P$ lants investing in $R \& D$ were less axected by the 1995 crisis. Their job turnover rates remained relatively unchanged and positive net change rates resumed after one year of employment loss. 


\section{Conclusions and future research directions}

We analyze performance of Mexican manufacturing ..rms between 1993 and 2000 , foll owing implementation of N orth-A merican Free-trade agreement. The plant-level panel data set was constructed combining information from three sources: Annual Industrial Survey, Industrial Census, and National Survey of Employment, Salaries, Technology and Training. The main goal of the empirical analysis is to evaluate the exect integration into international markets, import competition, and investment in technology on two dimensions of ..rm performance, productivity and job turnover. P roduction functions for two-digit SIC industries are estimated using a semiparametric approach which controls for selection and simultaneity biases. Est imates ar e used in subsequent analysis.

0 ur ..ndings suggest that the degree of integration in internat ional markets is a strong determinant of ..rm performance. Firms using larger shares of imported inputs show stronger productivity growth. B etter access to imported inputs has a stronger positive eaect of productivity for ..rms exporting larger shares of output. Results are mixed with respect to import competition. The most signi..cant results indicate that ..rms in facing stronger import competition do not become more productive. Particularly sharp are the results concerning the exect of using more imported inputs. Combined, these results suggest that better access to imported in puts is the more signi..cant vehicle for productivity enhancing exects of trade openness. Investment in technology is, by far, most strongly correlated with plant productivity.

The study of job turnover in relation to trade-related plant characteristics yielded very interesting results. Like, productivity, job turnover at ..rm level is strongly infuenced by the degree of integration in international markets, import competition, and $R \& D$ behavior. Firm performance dixers signi... cantly across years with high/low (or normal) turnover. W ith a high variation in job turnover over a relatively short period of time, Mexican economy during 1993-2000, provides the perfect case study. There are no signi..cant performance dixerences across integration, import competition, and investments in technology in low turnover year. In high turnover years, integration and expenditures in technology have a positive impact on ..rms performance, while import competition axects negatively ...rms' prospects.

$O$ ur results dixer from ..ndings of IDB (2002) in several respects. We found that ec ciency gap between exporters and non exporters and between large and small exporters grew signi..cantly during the period. Exporters with high share intermediate input users were those that gain most in terms of el ciency ${ }^{12}$. We also ..nd no evidence of enhanced productivity in import competing ..rms.

We are still in the process of checking alternative and complementary speci...cations and variables, regarding the exect of enhanced foreign competition in

\footnotetext{
${ }^{12} \mathrm{~T}$ he data base is the same as the one used in the IDB study: It excludes in-bond plants, called as well maquilad oras.
} 
local markets of ...nal products. Firstly, we are considering if the exect of import tarixs reductions during the period 1993-2000 have adequat ely been captured with the qualitative variables based on manufacturer's own perceptions. A n initial procedure to check the robustness of our results is to regress our rates of growth on plant's total factor productivity with variations in import tarias as independent variable - thereby rełecting some degree of myopic behavior.

A more elaborate procedure involves constructing a variable that indicates the phasing out category for the elimination of tarias to which the product belonged. Knowledge of their category allowed each producers to anticipate tarix levels for the rest of the decade. This step, as suggested in the text would require reestimation of production function, to the extent that exit decisions a source of bias in estimations - are also axected by this variable. (A similar line of argument suggests the inclusion of proxies of ..rms' ..nancial liquidity to explain their exit decisions). 


\section{R eferences}

B ernard, A., J . Bradford J ensen and P.K. Schott (2002) "Falling Trade Costs, Heterogeneous Firms, and Industry D ynamics" NBER Working Paper.

Calvo, G. (1986) "Incredible R eforms" M imeo, University of Pennsylvania.

Fernandez, R. and J. Portes (1998) "Returns to Regionalism: An Analysis of Nontraditional Gains from R egional Trade A geements" The W or ld B ank Economic Review. Vol 12. Num 2.

G riф th, R., S. R edding and J . Van R eenen (2002) "M apping the T wo Faces of $R \& D$ : Productivity Growth in a Panel of OECD Industries" L.S.E. M imeo.

Haddad, Mona, 1993 "How Trade Liberalization A xected Productivity in M orocco." PRD Working paper W PS 1096, The World Bank.

Holmes, T.J . and J. A. Schmitz (1995) "R esistance to New Technology and Trade B etween A reas" Federal R eserve B ank of M inneapolis Quarterly R eview. W inter. Vol 19, Nol.

IDB (2002) "Beyond Borders: The New Regionalism in Latin A merica". Inter A merican Development Bank. Washingt on, D.C.

INEGI (2001) Encuesta Industrial A nual. Instructivo para el Llenado del Cuestionario, pp. 19-22.

INEGI (2001) Metodology Censos Economicos, pp. 122.

K owalcyk, C. and Davis, D. (1998) "Tario Phase-Outs: Theory and Evidence from Gatt and NAFTA " In J exrey Frankel, ed. 1998. R egionalization of the W orld E conomy. Chicago U. P ress. NBER

K rishna, P. and D. Mitra (1997) "Trade Liberalization, M arket Discipline, and Productivity Growth: New Evidence from India. Processed, Brown University.

L evinsohn (1999) "E mployment R esponses to International Liber alization in Chile" J ournal of International Economics, 47, p.321-344.

L evinsohn, J . and Petrin (1999) "W hen Ind ustries B ecome M ore Productive, Do Firms?

Investigating Productive Dynamics" NBER Working Paper No 6893

L evinsohn, J. and Petrin (2000) "Estimating Production Functions Using In puts to Control For Unobservables" NBER W orking Paper No 7819

L opez-C or dova, E. (2002) “NA F TA and M exico's M anufacturing Productivity: An

E mpirical Investigation U sing M icro-level Data," mimeo, Inter-A merican Development B ank, Washington, D.C. J uly 15.

L opez-C or dova and M esquita M oreira, 2003, "R egional Integration and Productivity: The Experiences of Brazil and M exico" The Institute for the Integration of Latin A merica and the Caribean (INTAL) Working paper 14, J uly 2003.

Medina P., M. M elendez and K. Seim (2002) "Productivity Dynamics of the Colombian Manufacturing Sector". Processed. ID B Latin A merican R esearch Network. 
O lley, S. and Pakes, A; (1996) "T he Dynamics of P roductivity in the T elecommunications equipment Industry" Econometrica 64 (6), 1363-1298.

OECD (1996) "Trade Liberalisation Policies in M exico". OECD. Paris.

Pavnick, N. (2002) " "Trade L iberalization, Exit, and P roductivity Improvements: Evidence from Chilean Plants," Review of Economic Studies.

Prescott, E. (1998) "Needed: A theory of T otal Fact or Productivity" International Economic Review, A ugust 1998, Vol 39, No3.

R ay. D. (1998) D evelopment E conomics. Princeton University Press.

Rodrik, D. (1989) "Promises, Promises: Credible Policy Reforms via Signalling" The Economic J ournal 99 pp. 756-72.

Tybout, J. and M.D: Westbrook (1995) "Trade Liberalization and the Dimensions of $E \phi$ ciency Change in Mexican Manufacturing Industries" J ournal of International E conomics, 39. p. 53-78.

World Bank (2002) "Mexico Export Dynamics and Productivity, A nalyisis of M exican Manufacturing in the 1990s. 
Table 1. Tarix phase-out schedules

\begin{tabular}{||l|l||}
\hline \hline Tariø category & Phase-out schedule \\
\hline B & elimination upon the implementation of NAFTA, J an 1994 \\
\hline C & ...ve equal annual stages, between 1994 and 1998. \\
\hline D & ten equal annual stages, between 1994 and 2003. \\
\hline B+ & already free trade \\
(most textile tari $\ltimes s)$ & $\begin{array}{l}\text { seven stages: } 20 \% \text { in } 1994,0 \% \text { in } 1995, \\
10 \% \text { per year between } 1996 \text { and } 2000,30 \% \text { in } 2001 .\end{array}$ \\
\hline B8- & two stages: $50 \%$ in 1998 and $50 \%$ in 2001. \\
\hline \hline
\end{tabular}

Table 2. U.S. imports from M exico 1993-1998.

\begin{tabular}{||l|l|l|l|l|l|l|l||}
\hline \hline \multirow{2}{*}{ Sector } & \multicolumn{3}{|c|}{ value (millions USD) } & \multicolumn{3}{c||}{ share of total US imp orts (\%) } \\
\cline { 2 - 8 } Textiles & 1993 & 1996 & 1998 & 1993 & 1996 & 1997 & 1998 \\
A pparel & 204 & 775 & 1,343 & 1.88 & 6.89 & 8.46 & 8.92 \\
Furniture & 2,367 & 4,319 & 6,889 & 7.65 & 11.30 & 12.91 & 14.24 \\
Primary metal & 956 & 1,514 & 2,248 & 14.42 & 15.98 & 16.76 & 16.85 \\
Fabricated metal & 3,139 & 5,517 & 6,064 & 12.53 & 16.82 & 17.39 & 16.31 \\
Machinery & 1,124 & 1,957 & 3,193 & 7.23 & 9.43 & 11.80 & 13.04 \\
Electrical & 2,471 & 3,853 & 5,251 & 3.21 & 4.88 & 5.42 & 6.14 \\
Transportation & 8,888 & 10,293 & 10,020 & 11.62 & 17.94 & 17.95 & 18.07 \\
Scienti..c instr. & 6,015 & 15,034 & 17,741 & 6.22 & 12.40 & 12.20 & 12.08 \\
Total non-oil & 1,459 & 2,481 & 3,549 & 6.61 & 9.47 & 10.16 & 12.35 \\
\hline \hline
\end{tabular}


Table 3. The number of ..rms in the unblalanced panel and average employment by sector

\begin{tabular}{||l|l|l|l|l|l|l|l|l||}
\hline \hline Sector & 1993 & 1994 & 1995 & 1996 & 1997 & 1998 & 1999 & 2000 \\
\hline Observations & & & & & & & & \\
Food & 743 & 735 & 731 & 720 & 707 & 702 & 702 & 702 \\
Textiles & 747 & 733 & 704 & 674 & 634 & 630 & 627 & 627 \\
Wood & 150 & 148 & 142 & 133 & 129 & 129 & 127 & 127 \\
Paper & 328 & 325 & 321 & 318 & 317 & 316 & 317 & 317 \\
Chemical & 870 & 863 & 846 & 830 & 819 & 820 & 818 & 818 \\
Glass & 287 & 275 & 264 & 254 & 245 & 243 & 242 & 242 \\
Metals & 111 & 108 & 104 & 105 & 101 & 101 & 101 & 101 \\
Machinery & 1013 & 1005 & 981 & 948 & 924 & 920 & 915 & 915 \\
\multicolumn{1}{|l|}{} & & & & & & & \\
Mean employment & \multicolumn{1}{|l||}{} \\
Food & 365.9 & 368.9 & 368.8 & 378.2 & 391.1 & 404.5 & 418.3 & 421.2 \\
Textiles & 190.8 & 187.9 & 179.4 & 200.5 & 232.4 & 235.3 & 239.9 & 241.7 \\
Wood & 119.3 & 122.6 & 116.0 & 132.3 & 147.2 & 155.9 & 160.9 & 160.8 \\
Paper & 215.7 & 213.2 & 204.0 & 209.5 & 218.3 & 222.0 & 226.4 & 228.2 \\
Chemical & 205.9 & 206.0 & 199.8 & 210.9 & 226.4 & 239.2 & 243.7 & 249.3 \\
Glass & 233.2 & 234.0 & 224.6 & 232.1 & 249.4 & 262.7 & 266.4 & 271.5 \\
M etals & 443.8 & 442.2 & 429.2 & 442.6 & 476.0 & 470.3 & 457.8 & 454.2 \\
Machinery & 285.3 & 279.9 & 254.7 & 282.3 & 326.7 & 362.3 & 375.3 & 390.1 \\
\hline \hline
\end{tabular}


Table 4. Estimates of production functions. Balanced Panel, Fixed exects

\begin{tabular}{||l|l|l|l|l|l|l||}
\hline \hline sector & \multicolumn{2}{|c|}{ capital } & \multicolumn{2}{c|}{ labor unskilled } & \multicolumn{2}{c||}{ labor skilled } \\
\hline \multirow{3}{*}{ Food processing } & coex. & S.E. & coex. & S.E & coex. & S.E \\
\cline { 2 - 7 } Textiles & $0.247^{* *}$ & 0.021 & $0.430^{* *}$ & 0.027 & $0.225^{* *}$ & 0.022 \\
Wood & $0.101^{* *}$ & 0.021 & $0.577^{* *}$ & 0.029 & $0.196^{* *}$ & 0.025 \\
Paper & $0.238^{* *}$ & 0.051 & $0.554^{* *}$ & 0.061 & 0.060 & 0.060 \\
Chemical & $0.119^{* *}$ & 0.027 & $0.484^{* *}$ & 0.040 & $0.277^{* *}$ & 0.038 \\
Glass & $0.204^{* *}$ & 0.018 & $0.499^{* *}$ & 0.023 & $0.229^{* *}$ & 0.021 \\
Basic metals & $0.117^{* *}$ & 0.030 & $0.603^{* *}$ & 0.052 & 0.041 & 0.047 \\
Machinery & 0.079 & 0.059 & $0.596^{* *}$ & 0.060 & -0.038 & 0.060 \\
\hline \hline
\end{tabular}

**Signi..cant at 95 percent level. *Signi..cant at 90 percent level

Table 5. Estimates of production functions. Unbalanced Panel, F ixed exect

\begin{tabular}{||l|l|l|l|l|l|l||}
\hline \hline \multirow{2}{*}{ sector } & \multicolumn{2}{|c|}{ capital } & \multicolumn{2}{c|}{ labor unskilled } & \multicolumn{2}{c||}{ labor skilled } \\
\hline \multirow{3}{*}{ Food processing } & coea. & S.E. & coea. & S.E & coeq. & S.E \\
\cline { 2 - 7 } Textiles & $0.231^{* *}$ & 0.020 & $0.426^{* *}$ & 0.027 & $0.241^{* *}$ & 0.022 \\
Wood & $0.123^{* *}$ & 0.020 & $0.603^{* *}$ & 0.028 & $0.184^{* *}$ & 0.025 \\
Paper & $0.241^{* *}$ & 0.050 & $0.617^{* *}$ & 0.060 & 0.058 & 0.060 \\
Chemical & $0.127^{* *}$ & 0.026 & $0.485^{* *}$ & 0.040 & $0.277^{* *}$ & 0.038 \\
Glass & $0.206^{* *}$ & 0.017 & $0.507^{* *}$ & 0.023 & $0.229^{* *}$ & 0.021 \\
Basic metals & $0.145^{* *}$ & 0.031 & $0.671^{* *}$ & 0.051 & 0.016 & 0.046 \\
Machinery & $0.116^{* *}$ & 0.058 & $0.586^{* *}$ & 0.058 & -0.011 & 0.059 \\
\hline \hline
\end{tabular}

**Signi..cant at 95 percent level. *Signi..cant at 90 percent level 
Table 6. Estimates of production functions. Unbalanced Panel, Semiparametric estimation

\begin{tabular}{||l|l|l|l|l|l|l||c|c||}
\hline \hline sector & \multicolumn{2}{|c|}{ capital } & \multicolumn{2}{c||}{ labor unskilled } & \multicolumn{2}{c||}{ labor skilled } & \multicolumn{2}{c||}{ RT S } \\
\hline \multirow{3}{*}{ Food processing } & coeq. & S.E. & coeø. & S.E & coea. & S.E & Coea. & S.E \\
\cline { 2 - 9 } Textiles & $0.340^{* *}$ & 0.048 & $0.294^{* *}$ & 0.033 & $0.303^{* *}$ & 0.031 & 0.94 & 0.05 \\
Wood & $0.352^{* *}$ & 0.043 & $0.487^{* *}$ & 0.030 & $0.307^{* *}$ & 0.029 & $1.15^{* *}$ & 0.04 \\
Paper & $0.380^{* *}$ & 0.106 & $0.345^{* *}$ & 0.086 & $0.345^{* *}$ & 0.063 & 1.07 & 0.13 \\
Chemical & $0.196^{* *}$ & 0.085 & $0.375^{* *}$ & 0.047 & $0.391^{* *}$ & 0.030 & 0.96 & 0.10 \\
Glass & $0.522^{* *}$ & 0.036 & $0.137^{* *}$ & 0.036 & $0.500^{* *}$ & 0.031 & $1.16^{* *}$ & 0.05 \\
Basic metals & $0.351^{* *}$ & 0.109 & $0.148^{* *}$ & 0.053 & $0.388^{* *}$ & 0.049 & 0.89 & 0.11 \\
Machinery & $0.485^{* *}$ & 0.149 & $0.516^{* *}$ & 0.100 & $0.221^{* *}$ & 0.075 & 1.22 & 0.16 \\
\hline \hline
\end{tabular}

**Signi..cant at 95 percent level. *Signi..cant at 90 percent level

Note: bootstrap standard errors are presented

Table 7. Comparison of estimation results

\begin{tabular}{||l|l|l|c|c||}
\hline \hline \multirow{4}{*}{ sector } & capital & labor & \multicolumn{2}{|c||}{$M P_{B C} / M P_{W C}$} \\
\cline { 2 - 5 } Food processing & \%VAD & $\%$ VAD & OLS & Semiparametric estimation \\
\cline { 2 - 5 } Textiles & 0.700 & 0.380 & 0.86 & 0.479 \\
Wood & 0.568 & 0.690 & 0.792 & 0.383 \\
Paper & 0.563 & 0.642 & 2.206 & 0.207 \\
Chemical & 0.516 & 0.618 & 1.06 & 0.607 \\
Glass & 0.694 & 0.308 & 1.322 & 0.163 \\
Basic metals & 0.659 & 0.533 & 14.40 & 0.128 \\
Machinery & 0.527 & 0.725 & -22.66 & 0.955 \\
\hline \hline
\end{tabular}


Table 8. Change in productivity by sector.

\begin{tabular}{|c|c|c|c|c|c|c|c|}
\hline Sector & 1994 & 1995 & 1996 & 1997 & 1998 & 1999 & 2000 \\
\hline \multicolumn{8}{|c|}{ A ggregate productivity } \\
\hline Food & 0.045 & -0.003 & -0.032 & 0.015 & 0.113 & 0.178 & 0.260 \\
\hline Textile & 0.071 & 0.125 & 0.224 & 0.200 & 0.200 & 0.181 & 0.190 \\
\hline Wood & -0.030 & -0.137 & 0.019 & 0.049 & 0.067 & 0.137 & 0.144 \\
\hline Paper & 0.006 & 0.029 & 0.034 & 0.113 & 0.151 & 0.213 & 0.198 \\
\hline Chemical & 0.046 & 0.034 & 0.065 & 0.153 & 0.184 & 0.168 & 0.187 \\
\hline Glass & 0.121 & 0.020 & 0.279 & 0.359 & 0.419 & 0.450 & 0.503 \\
\hline M etals & 0.174 & 0.262 & 0.413 & 0.523 & 0.460 & 0.473 & 0.475 \\
\hline Machinery & 0.110 & 0.070 & 0.316 & 0.376 & 0.361 & 0.382 & .502 \\
\hline \multicolumn{8}{|c|}{ Unweight ed productivity } \\
\hline Food & 0.020 & 0.056 & 0.035 & 0.018 & 0.079 & 0.100 & 0.056 \\
\hline Textile & 0.045 & -0.043 & 0.039 & 0.059 & 0.008 & -0.026 & -0.053 \\
\hline Wood & -0.038 & -0.193 & 0.002 & -0.008 & 0.025 & 0.023 & -0.055 \\
\hline Paper & 0.053 & -0.038 & -0.016 & 0.142 & 0.167 & 0.172 & 0.173 \\
\hline Chemical & 0.023 & -0.021 & 0.050 & 0.038 & 0.069 & 0.040 & -0.008 \\
\hline Glass & 0.075 & -0.223 & -0.134 & 0.019 & 0.082 & 0.220 & 0.160 \\
\hline M etals & 0.070 & 0.098 & 0.188 & 0.288 & 0.390 & 0.380 & 0.281 \\
\hline Machinery & 0.052 & -0.125 & 0.021 & 0.095 & 0.105 & 0.055 & 0.073 \\
\hline \multicolumn{8}{|l|}{ Covariance } \\
\hline Food & 0.025 & -0.059 & -0.067 & -0.003 & 0.034 & 0.078 & 0.203 \\
\hline Textile & 0.025 & 0.169 & 0.185 & 0.142 & 0.192 & 0.207 & 0.244 \\
\hline Wood & 0.007 & 0.056 & 0.016 & 0.057 & 0.042 & 0.114 & 0.199 \\
\hline P aper & -0.047 & 0.067 & 0.049 & -0.030 & -0.016 & 0.040 & 0.025 \\
\hline Chemical & 0.023 & 0.055 & 0.015 & 0.115 & 0.115 & 0.128 & 0.195 \\
\hline Glass & 0.046 & 0.243 & 0.413 & 0.339 & 0.337 & 0.230 & 0.343 \\
\hline M etals & 0.104 & 0.163 & 0.225 & 0.235 & 0.070 & 0.093 & 0.193 \\
\hline Machinery & 0.058 & 0.195 & 0.295 & 0.281 & 0.256 & 0.326 & 0.430 \\
\hline
\end{tabular}


Table 9. The exect of the degree of integration in international markets on ..rm performance

\begin{tabular}{|c|c|c|c|c|c|c|}
\hline \multirow[b]{2}{*}{ Variable } & \multicolumn{2}{|c|}{ Productivity } & \multicolumn{2}{|c|}{ Empl. change (abs.) } & \multicolumn{2}{|c|}{ Net E mpl. change } \\
\hline & Coen. & S.E & Coex. & S.E. & Coex. & S.E \\
\hline Const & $4.493^{* *}$ & 2.121 & $3.589 * *$ & 0.277 & $-3.659 * *$ & 0.291 \\
\hline Year dummies & & & & & & \\
\hline 1994 & $0.038 * *$ & 0.018 & & - & - & - \\
\hline 1995 & $-0.146 * *$ & 0.024 & $0.068 * *$ & 0.013 & $-0.109 * *$ & 0.015 \\
\hline 1996 & $-0.084 * *$ & 0.026 & $0.047 * *$ & 0.013 & $-0.031 * *$ & 0.015 \\
\hline 1997 & -0.004 & 0.025 & $0.038 * *$ & 0.014 & 0.016 & 0.016 \\
\hline 1998 & 0.037 & 0.025 & $-0.036 * *$ & 0.012 & $0.080 * *$ & 0.014 \\
\hline 1999 & $0.059 * *$ & 0.026 & $-0.039 * *$ & 0.011 & $0.071^{* *}$ & 0.013 \\
\hline 2000 & 0.029 & 0.027 & $-0.079 * *$ & 0.009 & $0.060 * *$ & 0.011 \\
\hline size & $-3.381 * *$ & 1.650 & $-5.059 * *$ & 0.470 & $5.264^{* *}$ & 0.490 \\
\hline size^2 & $0.889 *$ & 0.465 & $2.785^{* *}$ & 0.293 & $-2.827 * *$ & 0.303 \\
\hline $\operatorname{size}^{\wedge} 3$ & $-0.099 *$ & 0.056 & $-0.675^{* *}$ & 0.079 & $0.667 * *$ & 0.081 \\
\hline size^4 & $0.004 *$ & 0.002 & $0.060 * *$ & 0.008 & $-0.058 * *$ & 0.008 \\
\hline \multicolumn{7}{|c|}{ Interactions export status $\mathrm{x}$ import status } \\
\hline exp0imp2 & $0.111 * *$ & 0.054 & -0.019 & 0.017 & $0.052^{* *}$ & 0.021 \\
\hline explimp1 & $0.059 * *$ & 0.029 & -0.014 & 0.010 & $0.027 * *$ & 0.012 \\
\hline exp1imp2 & $0.072 * *$ & 0.035 & $-0.038 * *$ & 0.010 & $0.023 *$ & 0.012 \\
\hline exp2imp1 & $-0.167 * *$ & 0.024 & -0.002 & 0.015 & $0.041 * *$ & 0.019 \\
\hline exp2imp2 & -0.027 & 0.146 & $-0.028 * *$ & 0.011 & $0.030 * *$ & 0.013 \\
\hline
\end{tabular}


Table 9 (continued). The exect of the degree of integration in international markets on ..rm performance.

\begin{tabular}{|c|c|c|c|c|c|c|}
\hline \multirow[b]{2}{*}{ Variable } & \multicolumn{2}{|c|}{ Productivity } & \multicolumn{2}{|c|}{ Empl.change (abs.) } & \multicolumn{2}{|c|}{ Net $E$ mpl. change } \\
\hline & Coen. & S.E. & Coex. & S.E. & Coex. & S.E. \\
\hline & \multicolumn{6}{|c|}{ Interactions export status $x$ import status $x$ year } \\
\hline exp0imp2 & & & & & & \\
\hline 1994 & 0.007 & 0.043 & - & - & - & - \\
\hline 1995 & $0.144 * *$ & 0.054 & $-0.060 * *$ & 0.022 & 0.006 & 0.027 \\
\hline 1996 & $0.108 *$ & 0.058 & -0.015 & 0.029 & 0.014 & 0.035 \\
\hline 1997 & -0.020 & 0.061 & $-0.055 * *$ & 0.024 & 0.014 & 0.029 \\
\hline 1998 & 0.016 & 0.057 & 0.036 & 0.029 & $-0.063^{*}$ & 0.034 \\
\hline 1999 & 0.004 & 0.059 & -0.010 & 0.020 & $-0.060 * *$ & 0.024 \\
\hline 2000 & 0.026 & 0.064 & 0.028 & 0.021 & $-0.056 * *$ & 0.025 \\
\hline \multicolumn{7}{|l|}{ explimp1 } \\
\hline 1994 & -0.024 & 0.025 & - & - & - & - \\
\hline 1995 & 0.046 & 0.032 & $-0.032 * *$ & 0.015 & 0.020 & 0.019 \\
\hline 1996 & $0.080 * *$ & 0.035 & -0.021 & 0.017 & 0.076 & $0.020 *$ \\
\hline 1997 & 0.032 & 0.035 & -0.009 & 0.018 & 0.049 & $0.021 * *$ \\
\hline 1998 & -0.016 & 0.035 & $0.024 *$ & 0.015 & -0.040 & $0.017 * *$ \\
\hline 1999 & -0.032 & 0.036 & 0.009 & 0.013 & -0.063 & $0.016 * *$ \\
\hline 2000 & -0.049 & 0.038 & $0.030 * *$ & 0.011 & -0.051 & $0.014 * *$ \\
\hline \multicolumn{7}{|l|}{ explimp2 } \\
\hline 1994 & 0.019 & 0.026 & - & - & - & - \\
\hline 1995 & $0.183 * *$ & 0.035 & -0.045 & 0.015 & 0.055 & 0.018 \\
\hline 1996 & $0.210 * *$ & 0.036 & -0.015 & 0.017 & 0.111 & 0.020 \\
\hline 1997 & $0.167 * *$ & 0.037 & -0.019 & 0.016 & 0.071 & 0.019 \\
\hline 1998 & $0.155^{* *}$ & 0.037 & 0.045 & 0.014 & 0.000 & 0.017 \\
\hline 1999 & $0.087 * *$ & 0.041 & 0.038 & 0.013 & -0.037 & 0.016 \\
\hline 2000 & $0.093 * *$ & 0.041 & 0.070 & 0.011 & -0.034 & 0.014 \\
\hline
\end{tabular}


Table 9 (continued). The exect of the degree of integration in international markets on ..rm performance.

\begin{tabular}{|c|c|c|c|c|c|c|}
\hline \multirow[b]{2}{*}{ Variable } & \multicolumn{2}{|c|}{ Productivity } & \multicolumn{2}{|c|}{ Empl. change (abs.) } & \multicolumn{2}{|c|}{ Net empl. change } \\
\hline & Coeq. & S.E. & Coen. & S.E. & Coep. & S.E \\
\hline & \multicolumn{6}{|c|}{ Interactions export status $x$ import status $x$ year } \\
\hline exp2imp1 & & & & & & \\
\hline 1994 & -0.005 & 0.048 & - & - & - & - \\
\hline 1995 & $0.240 * *$ & 0.057 & $-0.046 * *$ & 0.021 & $0.114 * *$ & 0.029 \\
\hline 1996 & $0.226 * *$ & 0.062 & -0.019 & 0.022 & $0.133 * *$ & 0.027 \\
\hline 1997 & $0.148 * *$ & 0.063 & -0.012 & 0.025 & 0.045 & 0.031 \\
\hline 1998 & 0.085 & 0.063 & 0.014 & 0.019 & $-0.062 * *$ & 0.025 \\
\hline 1999 & -0.050 & 0.070 & 0.024 & 0.020 & $-0.086 * *$ & 0.026 \\
\hline 2000 & -0.002 & 0.068 & $0.039 * *$ & 0.019 & $-0.114 * *$ & 0.025 \\
\hline exp2imp2 & & & & & & \\
\hline 1994 & 0.051 & 0.042 & - & - & - & - \\
\hline 1995 & $0.283 * *$ & 0.044 & $-0.054 * *$ & 0.016 & $0.076 * *$ & 0.020 \\
\hline 1996 & $0.280 * *$ & 0.045 & -0.009 & 0.019 & $0.112 * *$ & 0.023 \\
\hline 1997 & $0.193 * *$ & 0.043 & -0.011 & 0.018 & $0.088 * *$ & 0.021 \\
\hline 1998 & $0.162 * *$ & 0.042 & $0.049 * *$ & 0.016 & -0.014 & 0.019 \\
\hline 1999 & $0.102 * *$ & 0.043 & $0.039 * *$ & 0.015 & $-0.074 * *$ & 0.018 \\
\hline 2000 & $0.119 * *$ & 0.044 & $0.076^{* *}$ & 0.013 & $-0.049 * *$ & 0.017 \\
\hline
\end{tabular}


Table 10. The exect of import competition on ..rm performance. Import competition is a dummy variable

\begin{tabular}{|c|c|c|c|c|c|c|}
\hline & \multicolumn{2}{|c|}{ Productivity } & \multicolumn{2}{|c|}{ Emp. change (abs.) } & \multicolumn{2}{|c|}{ Net emp.change } \\
\hline Variable & Coen. & S.E & Coen & S.E & Coex & S.E \\
\hline Const & $4.485 * *$ & 2.144 & $3.583^{* *}$ & 0.278 & $-3.644 * *$ & 0.296 \\
\hline Year dummies & & & & & & \\
\hline 1994 & $0.023^{*}$ & 0.014 & - & - & - & - \\
\hline 1995 & $-0.052 * *$ & 0.018 & $0.027^{* *}$ & 0.007 & $-0.066 * *$ & 0.009 \\
\hline 1996 & 0.005 & 0.019 & $0.021^{* *}$ & 0.007 & $0.016^{*}$ & 0.009 \\
\hline 1997 & $0.050 * *$ & 0.019 & $0.018^{* *}$ & 0.008 & $0.036 * *$ & 0.009 \\
\hline 1998 & $0.090 * *$ & 0.019 & $-0.016 * *$ & 0.007 & $0.038 * *$ & 0.008 \\
\hline 1999 & $0.096 * *$ & 0.019 & $-0.022 * *$ & 0.006 & $0.018^{* *}$ & 0.008 \\
\hline 2000 & $0.055^{* *}$ & 0.021 & $-0.049 * *$ & 0.006 & $0.011 *$ & 0.007 \\
\hline size & $-3.419 * *$ & 1.666 & $-5.034 * *$ & 0.472 & $5.201^{* *}$ & 0.498 \\
\hline size2 & $0.907 * *$ & 0.469 & $2.754^{* *}$ & 0.293 & $-2.762 * *$ & 0.308 \\
\hline size3 & $-0.101 *$ & 0.057 & $-0.664 * *$ & 0.079 & $0.648^{* *}$ & 0.083 \\
\hline size4 & $0.004 *$ & 0.003 & $0.059 * *$ & 0.008 & $-0.056 * *$ & 0.008 \\
\hline impcomp & 0.003 & 0.025 & -0.007 & 0.007 & -0.011 & 0.008 \\
\hline \multicolumn{7}{|c|}{ Interactions import competition $x$ year } \\
\hline 1994 & $0.031 *$ & 0.019 & & & - & - \\
\hline 1995 & -0.003 & 0.025 & $0.023 * *$ & 0.010 & $-0.021 *$ & 0.013 \\
\hline 1996 & 0.036 & 0.026 & $0.029 * *$ & 0.012 & $0.043 * *$ & 0.014 \\
\hline 1997 & 0.022 & 0.027 & 0.018 & 0.011 & $0.049 * *$ & 0.014 \\
\hline 1998 & -0.018 & 0.027 & 0.009 & 0.010 & $0.047 * *$ & 0.012 \\
\hline 1999 & $-0.051 *$ & 0.028 & -0.003 & 0.009 & $0.021^{*}$ & 0.011 \\
\hline 2000 & -0.023 & 0.029 & 0.011 & 0.008 & $0.021 * *$ & 0.010 \\
\hline
\end{tabular}


Table 11. The exect of investments in $R \& D$ on ..rm performance

\begin{tabular}{|c|c|c|c|c|c|c|}
\hline \multirow[b]{2}{*}{ Variable } & \multicolumn{2}{|c|}{ Productivity } & \multicolumn{2}{|c|}{ E mpl. change (abs.) } & \multicolumn{2}{|c|}{ Net empl. change } \\
\hline & coes. & $\overline{S . E}$ & coex. & $\overline{S . E}$ & coen. & S.E. \\
\hline Constant & $4.518^{* *}$ & 2.148 & $3.602 * *$ & 0.276 & $-3.681 * *$ & 0.294 \\
\hline 1994 & $0.025 *$ & 0.016 & - & - & 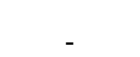 & - \\
\hline 1995 & $-0.114 * *$ & 0.021 & $0.055^{* *}$ & 0.011 & $-0.095 * *$ & 0.013 \\
\hline 1996 & $-0.038 *$ & 0.023 & $0.061 * *$ & 0.013 & $0.014 * *$ & 0.015 \\
\hline 1997 & 0.009 & 0.023 & $0.035 * *$ & 0.013 & $0.042 * *$ & 0.014 \\
\hline 1998 & $0.042^{*}$ & 0.023 & $-0.035 * *$ & 0.010 & $0.071 * *$ & 0.012 \\
\hline 1999 & 0.020 & 0.024 & $-0.048 * *$ & 0.009 & $0.052 * *$ & 0.011 \\
\hline 2000 & -0.005 & 0.024 & $-0.078 * *$ & 0.008 & $0.045 * *$ & 0.010 \\
\hline size & $-3.435 * *$ & 1.671 & $-5.076 * *$ & 0.468 & $5.269 * *$ & 0.495 \\
\hline size^2 & $0.912 *$ & 0.471 & $2.795 * *$ & 0.291 & $-2.814 * *$ & 0.306 \\
\hline size^3 & $-0.103^{*}$ & 0.057 & $-0.677 * *$ & 0.079 & $0.660 * *$ & 0.082 \\
\hline $\operatorname{size}^{\wedge} 4$ & $0.004^{*}$ & 0.003 & $0.060 * *$ & 0.008 & $-0.057 * *$ & 0.008 \\
\hline \multicolumn{7}{|c|}{ Invest ment status ( no $R \& D$ investments excluded) } \\
\hline Small $R \& D$ inv. & $0.078 * *$ & 0.026 & $-0.040 * *$ & 0.008 & $0.032 * *$ & 0.010 \\
\hline$L$ arge $R \& D$ inv. & $0.113 * *$ & 0.051 & $-0.047 * *$ & 0.011 & $0.041 * *$ & 0.014 \\
\hline
\end{tabular}


Table 11 (continued). T he exect of investments in $R \& D$ on ..rm performance

\begin{tabular}{|c|c|c|c|c|c|c|}
\hline \multirow[b]{2}{*}{ Variable } & \multicolumn{2}{|c|}{ Productivity } & \multicolumn{2}{|c|}{ E mpl. change (abs.) } & \multicolumn{2}{|c|}{ Net empl. change } \\
\hline & coex. & S.E & coex. & S.E & coep. & S.E. \\
\hline \multicolumn{7}{|c|}{ Interactions investment status $\mathrm{x}$ year } \\
\hline \multicolumn{7}{|c|}{ Small $R \& D$ investments } \\
\hline 1994 & 0.020 & 0.020 & - & - & - & - \\
\hline 1995 & $0.101 * *$ & 0.026 & $-0.028 * *$ & 0.012 & $0.033^{* *}$ & 0.015 \\
\hline 1996 & $0.092 * *$ & 0.028 & $-0.044 * *$ & 0.014 & $0.035^{* *}$ & 0.016 \\
\hline 1997 & $0.072 * *$ & 0.029 & -0.015 & 0.014 & $0.030 *$ & 0.016 \\
\hline 1998 & 0.049* & 0.029 & $0.032 * *$ & 0.011 & $-0.022 *$ & 0.014 \\
\hline 1999 & $0.067 * *$ & 0.030 & $0.037 * *$ & 0.011 & $-0.036 * *$ & 0.013 \\
\hline 2000 & 0.059* & 0.031 & $0.052 * *$ & 0.009 & $-0.037 * *$ & 0.012 \\
\hline \multicolumn{7}{|c|}{ Large $R \& D$ invest ments } \\
\hline 1994 & 0.045 & 0.032 & - & - & - & - \\
\hline 1995 & $0.136 * *$ & 0.045 & -0.024 & 0.017 & 0.013 & 0.020 \\
\hline 1996 & $0.150 * *$ & 0.051 & -0.026 & 0.020 & 0.025 & 0.024 \\
\hline 1997 & $0.159 * *$ & 0.049 & 0.003 & 0.021 & -0.003 & 0.025 \\
\hline 1998 & $0.150 * *$ & 0.053 & $0.068 * *$ & 0.019 & 0.001 & 0.023 \\
\hline 1999 & $0.171 * *$ & 0.052 & $0.050 * *$ & 0.015 & $-0.046 * *$ & 0.019 \\
\hline 2000 & $0.193 * *$ & 0.055 & $0.068 * *$ & 0.014 & $-0.034 *$ & 0.018 \\
\hline
\end{tabular}


Table 12. Rates of job creation and distruction

\begin{tabular}{||l|l|l|l|l|l|l|l||}
\hline \hline Sector & $93-94$ & $94-95$ & $95-96$ & $96-97$ & $97-98$ & $98-99$ & $99-00$ \\
\hline R ate of job creation \\
Food & 0.058 & 0.062 & 0.065 & 0.067 & 0.065 & 0.068 & 0.044 \\
Textiles & 0.054 & 0.039 & 0.125 & 0.130 & 0.063 & 0.065 & 0.057 \\
Wood & 0.095 & 0.051 & 0.131 & 0.135 & 0.099 & 0.066 & 0.069 \\
Paper & 0.048 & 0.032 & 0.059 & 0.065 & 0.055 & 0.068 & 0.041 \\
Chemical & 0.056 & 0.037 & 0.073 & 0.086 & 0.089 & 0.062 & 0.056 \\
Glass & 0.051 & 0.031 & 0.054 & 0.070 & 0.068 & 0.052 & 0.053 \\
M etals & 0.044 & 0.054 & 0.077 & 0.070 & 0.060 & 0.021 & 0.030 \\
Machinery & 0.052 & 0.035 & 0.131 & 0.150 & 0.125 & 0.081 & 0.086 \\
R ate of job distruction & & & & & \\
Food & 0.060 & 0.069 & 0.055 & 0.052 & 0.039 & 0.034 & 0.037 \\
Textiles & 0.091 & 0.126 & 0.055 & 0.047 & 0.057 & 0.050 & 0.049 \\
Wood & 0.083 & 0.140 & 0.069 & 0.059 & 0.041 & 0.050 & 0.069 \\
Paper & 0.070 & 0.089 & 0.042 & 0.027 & 0.041 & 0.045 & 0.032 \\
Chemical & 0.064 & 0.087 & 0.039 & 0.029 & 0.037 & 0.046 & 0.033 \\
Glass & 0.089 & 0.108 & 0.063 & 0.036 & 0.024 & 0.043 & 0.034 \\
M etals & 0.072 & 0.120 & 0.036 & 0.036 & 0.072 & 0.048 & 0.038 \\
Machinery & 0.079 & 0.152 & 0.062 & 0.029 & 0.027 & 0.051 & 0.047 \\
\hline \hline
\end{tabular}


Table 12 (continued). Rates of job creation and distruction

\begin{tabular}{|c|c|c|c|c|c|c|c|}
\hline Sector & 93-94 & $94-95$ & $95-96$ & $96-97$ & $97-98$ & 98-99 & $99-00$ \\
\hline \multicolumn{8}{|c|}{$R$ ate of net change } \\
\hline Food & -0.002 & -0.007 & 0.010 & 0.016 & 0.027 & 0.034 & 0.007 \\
\hline Textiles & -0.037 & -0.087 & 0.069 & 0.083 & 0.006 & 0.015 & 0.007 \\
\hline Wood & 0.013 & -0.089 & 0.062 & 0.076 & 0.058 & 0.016 & 0.000 \\
\hline Paper & -0.022 & -0.057 & 0.018 & 0.038 & 0.014 & 0.023 & 0.008 \\
\hline Chemical & -0.008 & -0.050 & 0.035 & 0.057 & 0.051 & 0.016 & 0.023 \\
\hline Glass & -0.038 & -0.076 & -0.010 & 0.035 & 0.044 & 0.010 & 0.019 \\
\hline M etals & -0.027 & -0.066 & 0.040 & 0.034 & -0.012 & -0.027 & -0.008 \\
\hline Machinery & -0.027 & -0.117 & 0.069 & 0.121 & 0.099 & 0.030 & 0.039 \\
\hline \multicolumn{8}{|c|}{$R$ ate of reallocation } \\
\hline Food & 0.118 & 0.131 & 0.120 & 0.119 & 0.104 & 0.102 & 0.081 \\
\hline Textiles & 0.145 & 0.165 & 0.180 & 0.176 & 0.119 & 0.116 & 0.106 \\
\hline Wood & 0.178 & 0.191 & 0.200 & 0.193 & 0.141 & 0.116 & 0.138 \\
\hline Paper & 0.119 & 0.121 & 0.101 & 0.092 & 0.096 & 0.114 & 0.073 \\
\hline Chemical & 0.121 & 0.124 & 0.112 & 0.115 & 0.126 & 0.108 & 0.089 \\
\hline Glass & 0.140 & 0.139 & 0.117 & 0.106 & 0.092 & 0.095 & 0.087 \\
\hline M etals & 0.116 & 0.175 & 0.113 & 0.106 & 0.132 & 0.069 & 0.069 \\
\hline Machinery & 0.131 & 0.188 & 0.193 & 0.179 & 0.152 & 0.131 & 0.133 \\
\hline \multicolumn{8}{|c|}{$R$ ate of excess reallocation } \\
\hline Food & 0.116 & 0.124 & 0.110 & 0.104 & 0.077 & 0.068 & 0.074 \\
\hline Textiles & 0.108 & 0.079 & 0.111 & 0.093 & 0.113 & 0.101 & 0.099 \\
\hline Wood & 0.165 & 0.102 & 0.138 & 0.117 & 0.083 & 0.100 & 0.138 \\
\hline Paper & 0.097 & 0.064 & 0.083 & 0.055 & 0.083 & 0.091 & 0.065 \\
\hline Chemical & 0.113 & 0.073 & 0.077 & 0.058 & 0.075 & 0.092 & 0.067 \\
\hline Glass & 0.101 & 0.062 & 0.107 & 0.071 & 0.048 & 0.085 & 0.067 \\
\hline M etals & 0.089 & 0.109 & 0.073 & 0.072 & 0.120 & 0.042 & 0.061 \\
\hline Machinery & 0.104 & 0.071 & 0.124 & 0.058 & 0.054 & 0.102 & 0.094 \\
\hline
\end{tabular}


Figure 1. The exect of trade int egration on productivity

The effect of trade integration on productivity

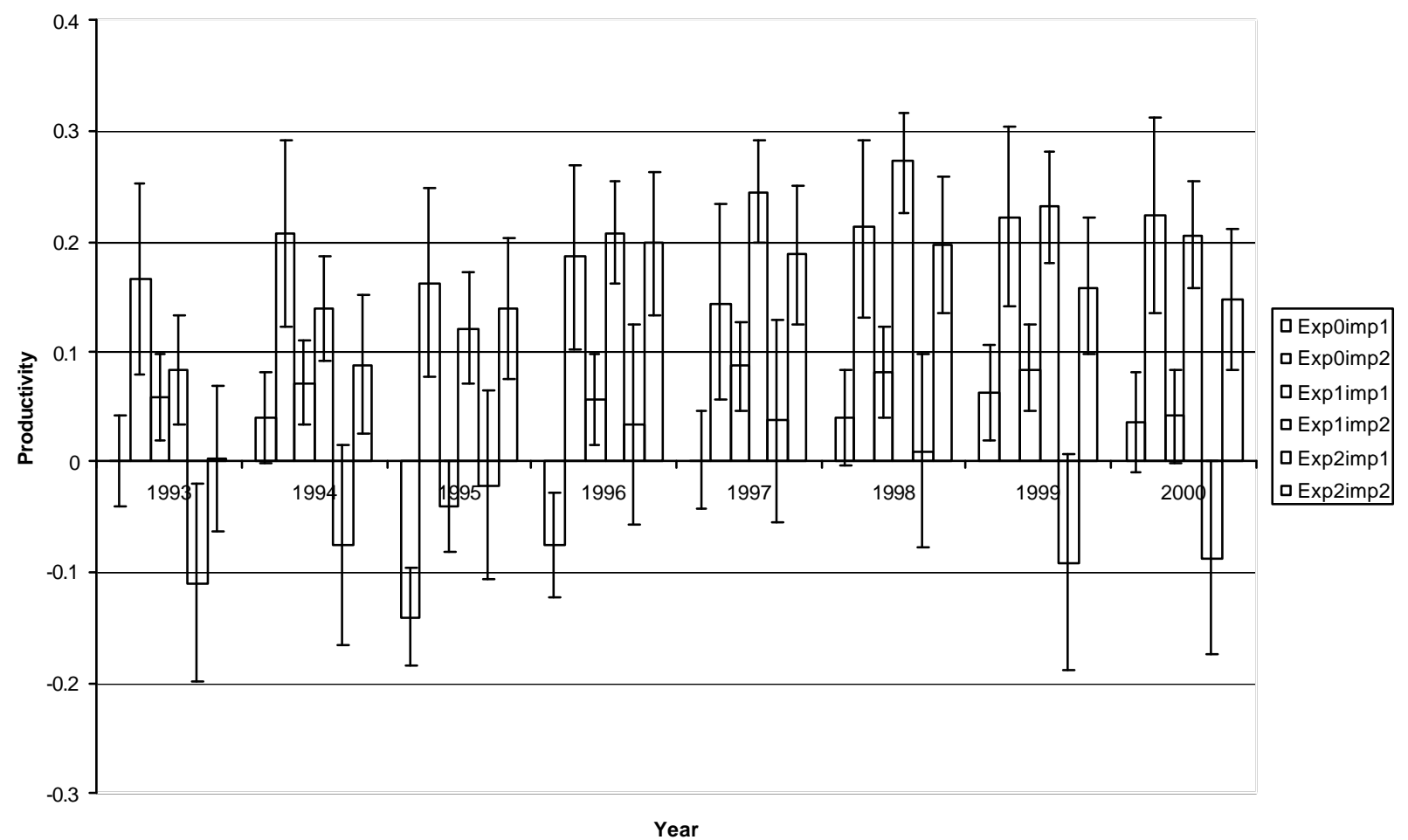


Figure 2. The exect of import competition on productivity

The effect of import competition on productivity

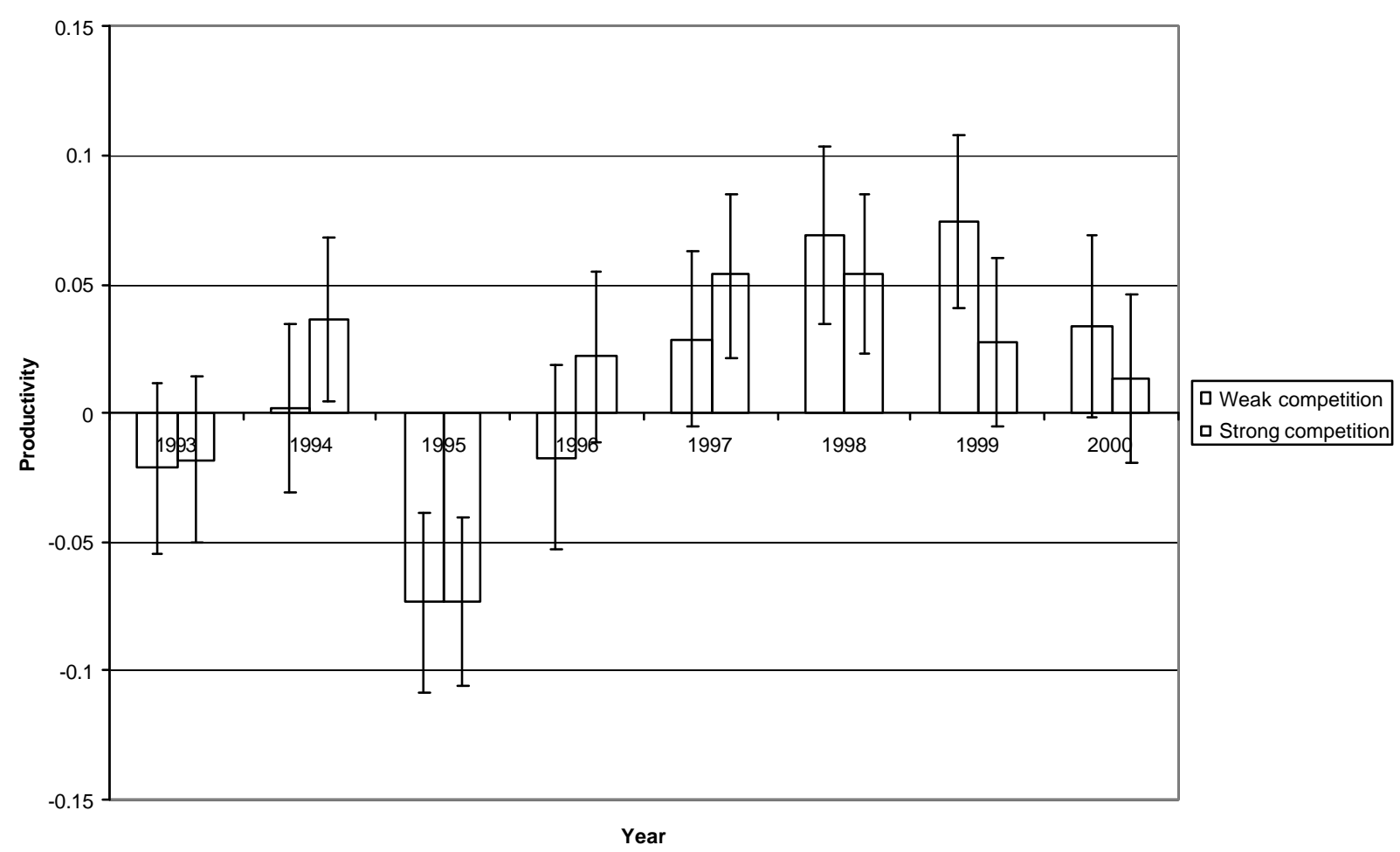


Figure 3. The exect of trade int egration on the rate of net job change

Rate of net job change

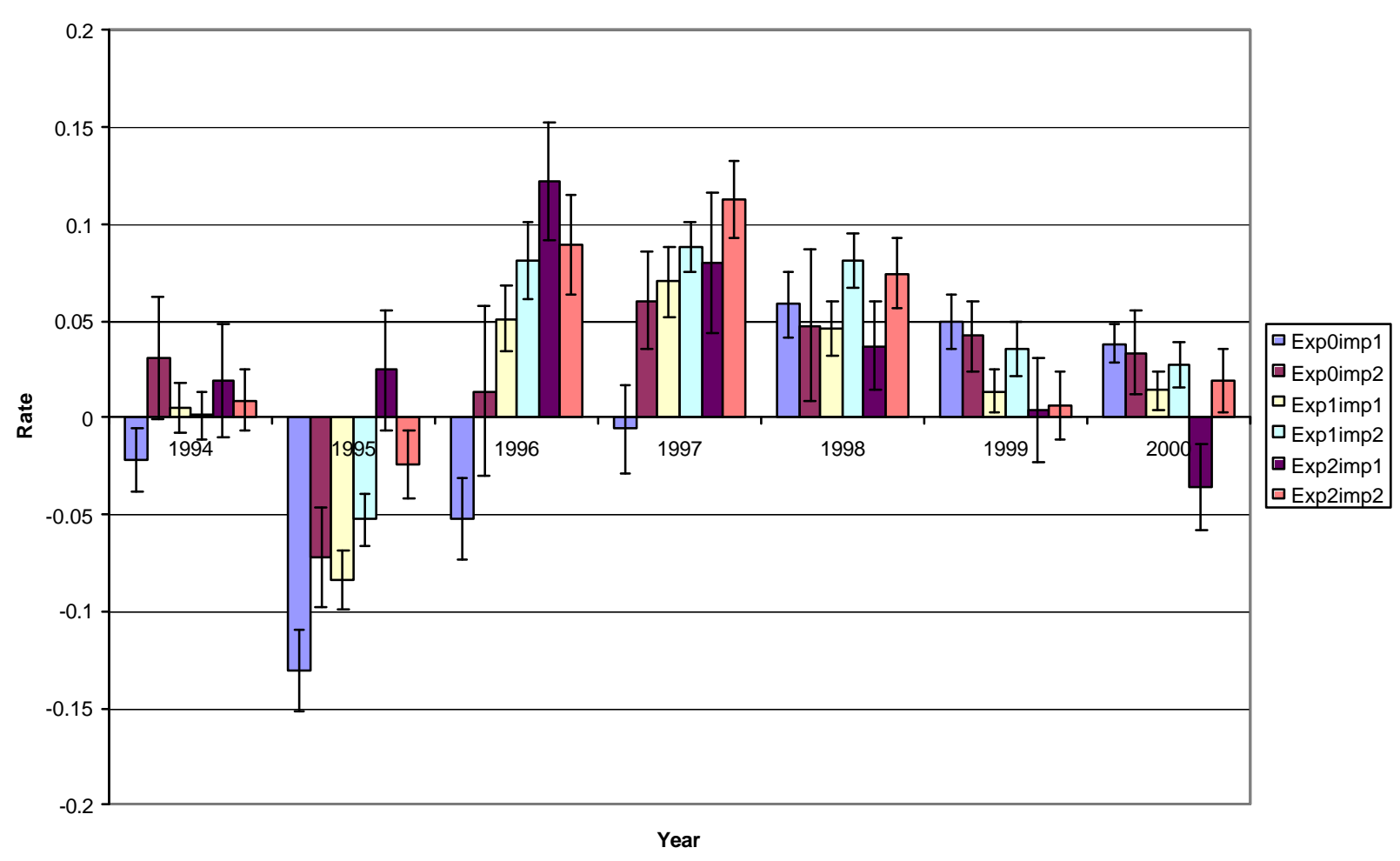


Figure 4. The exect of trade int egration on the rate of job reallocation

Rate of job reallocation

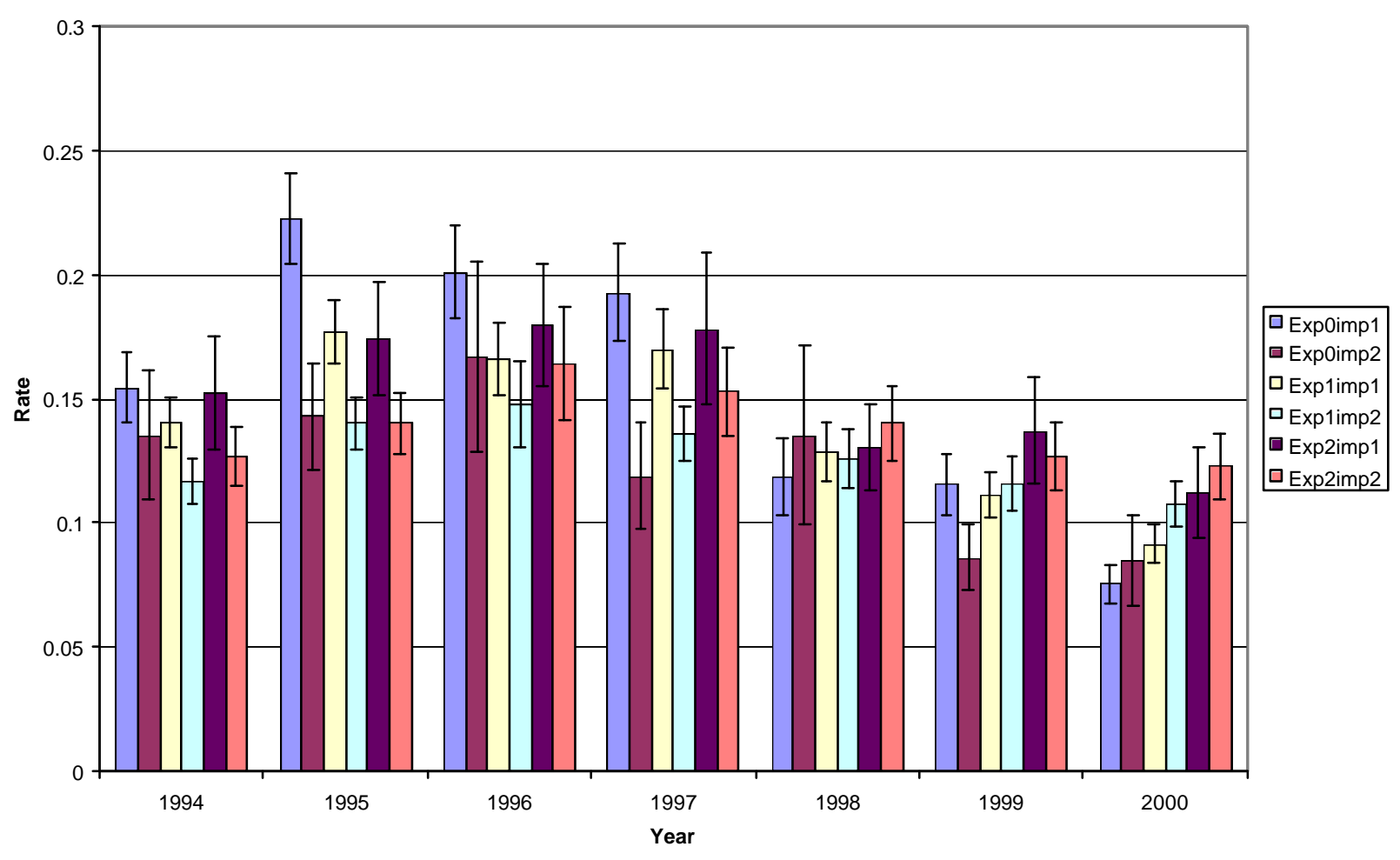


Figure 5. The exect of import competition on the rate of net job change

Rate of net job creation

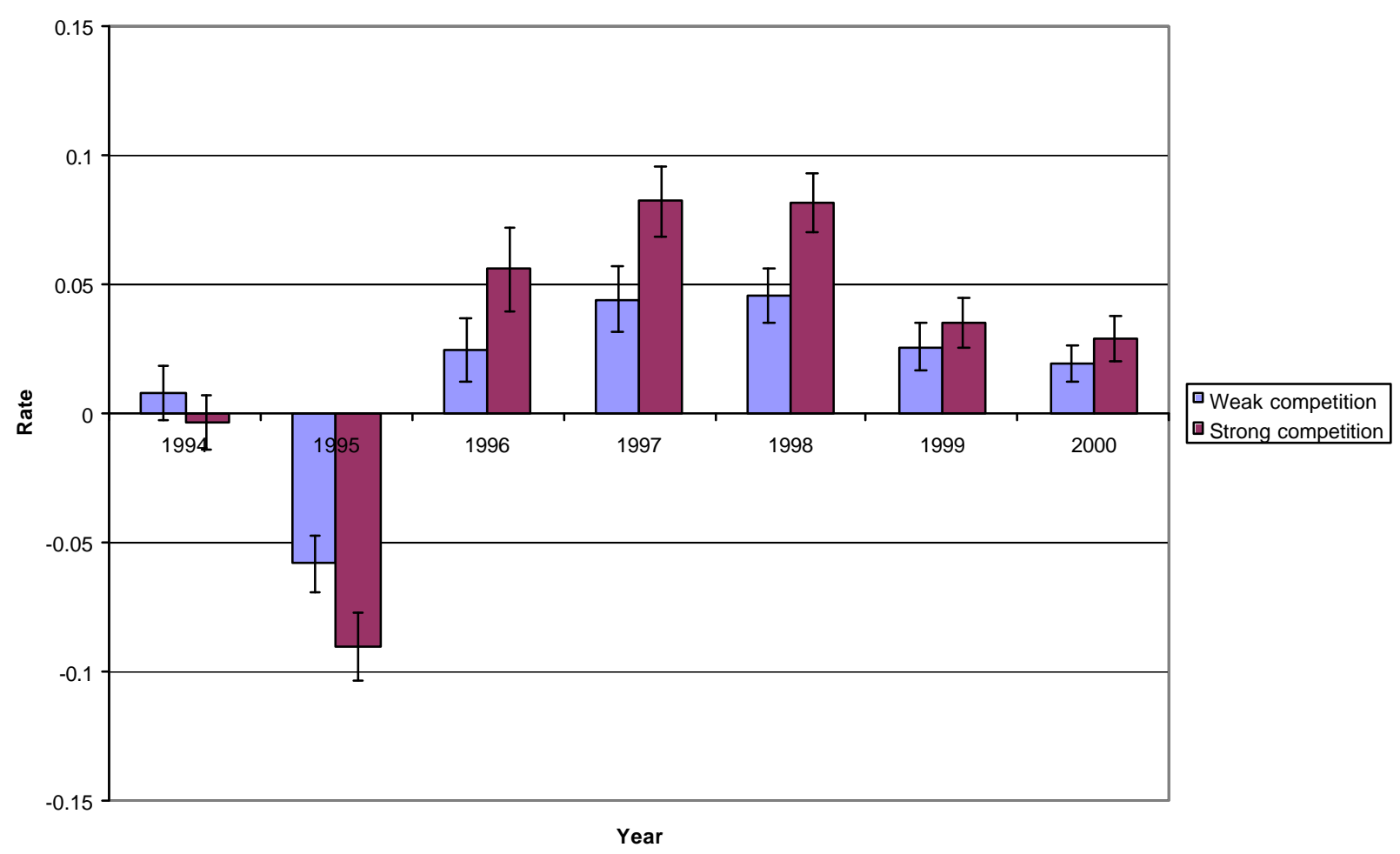


Figure 6. The exect of import competition on the rate of job reallocation

Job reallocation rate

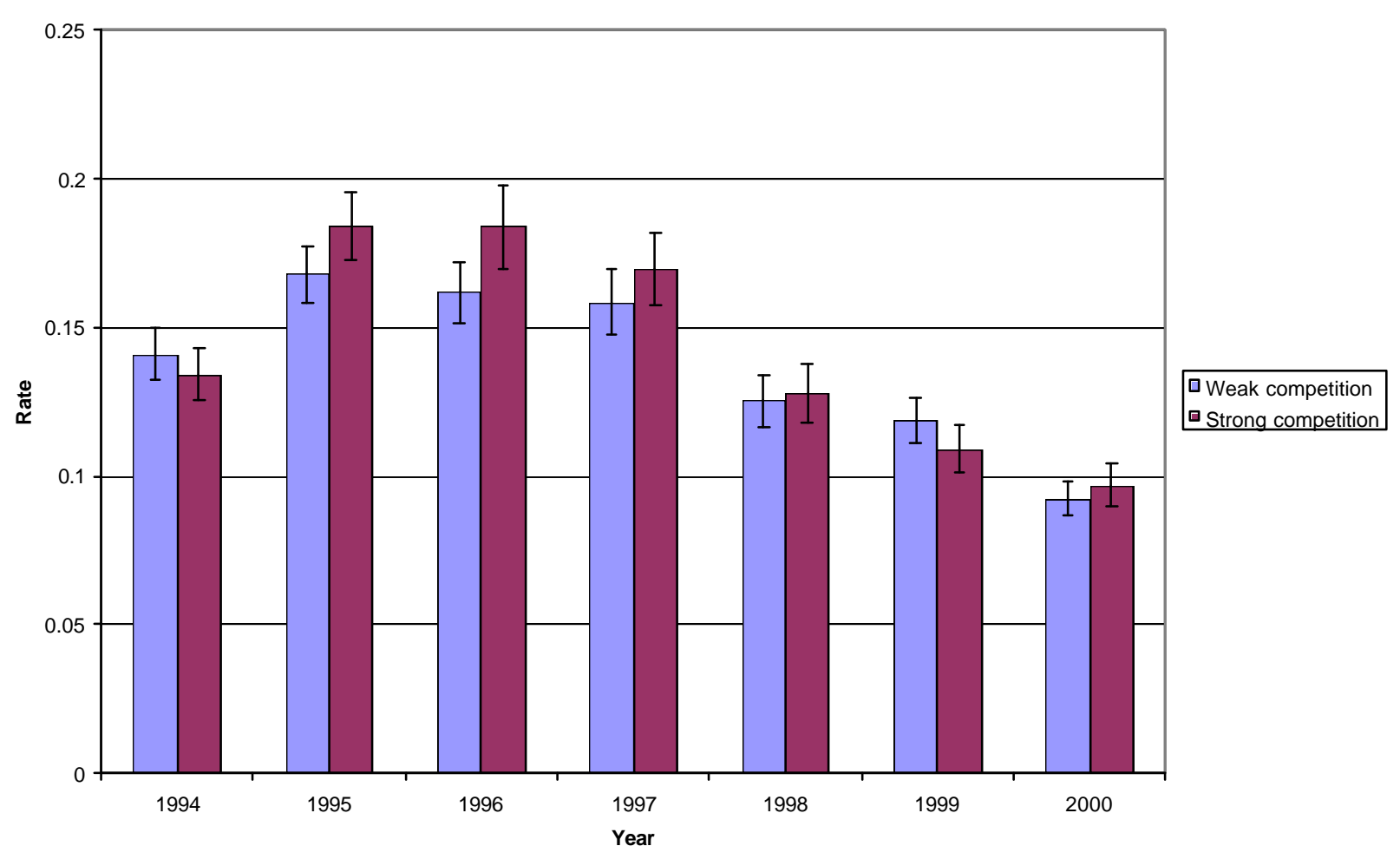


Figure 7. The exect of expenditure in technology on productivity

The effect of expenditure in R\&D on productivity

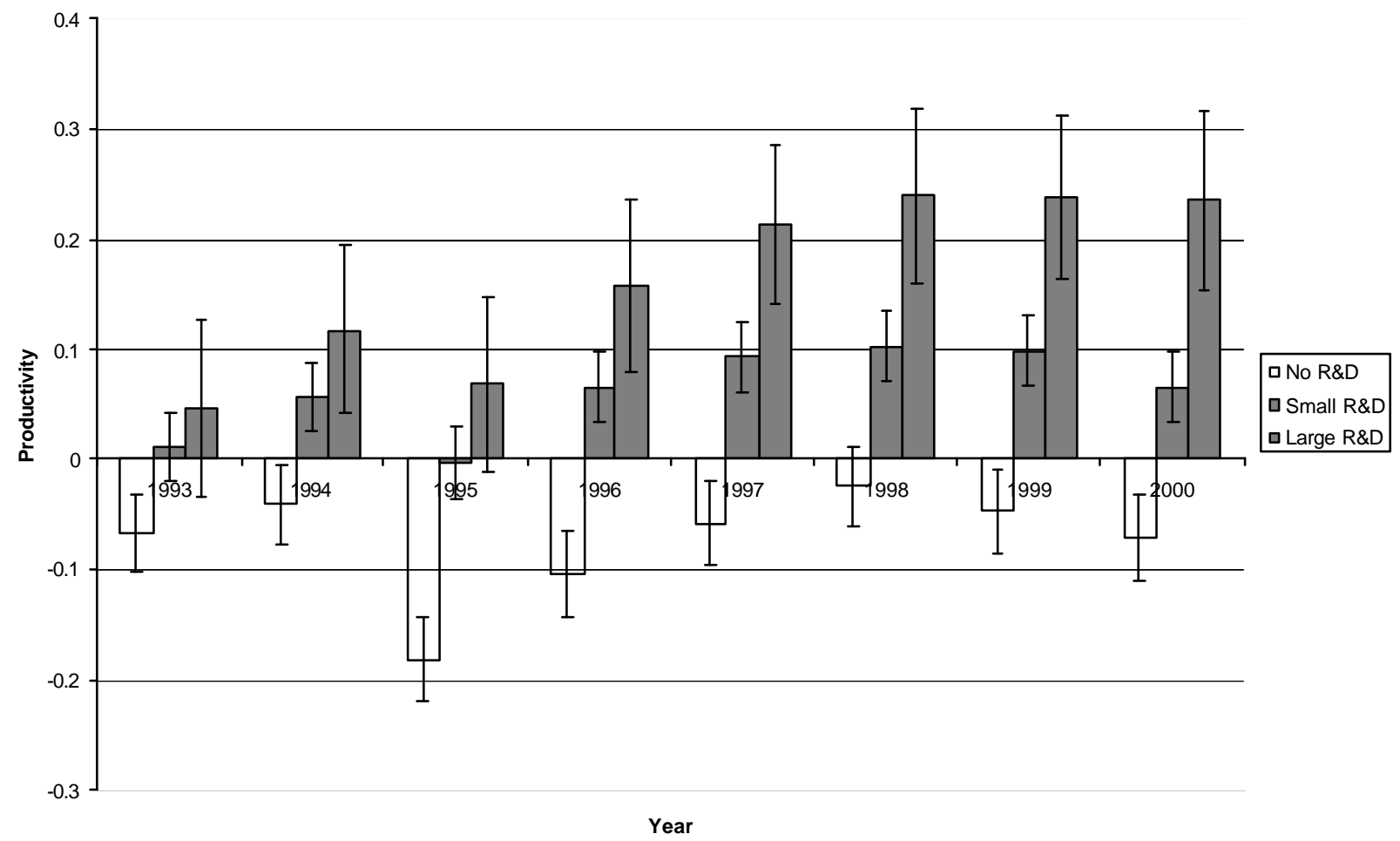


Figure 8. The exect of expenditure in technology on the rate of net job change

Job reallocation: rate of net change

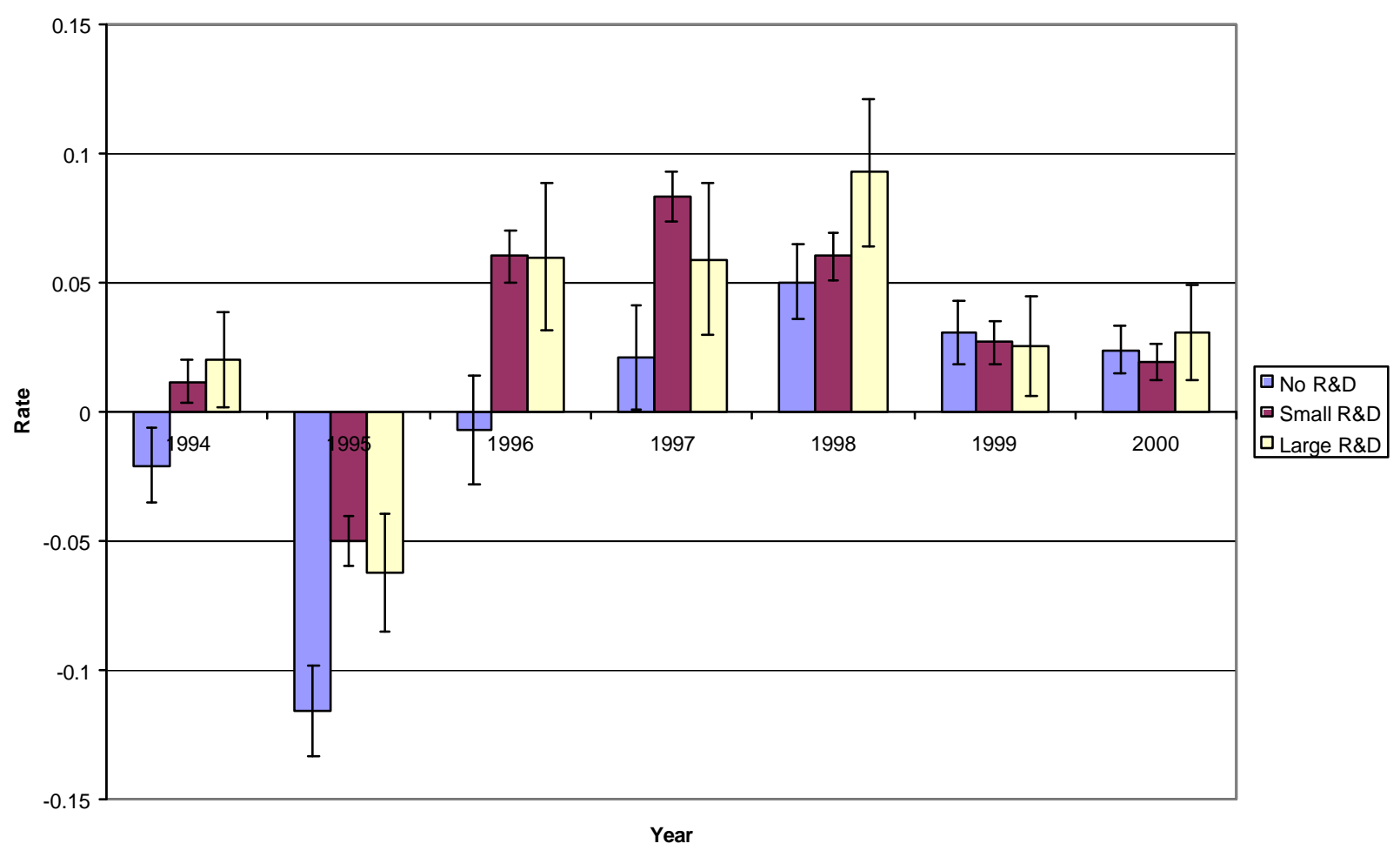


Figure 9. The exect of expenditure in technology on the rate of job reallocation

Job reallocation rate

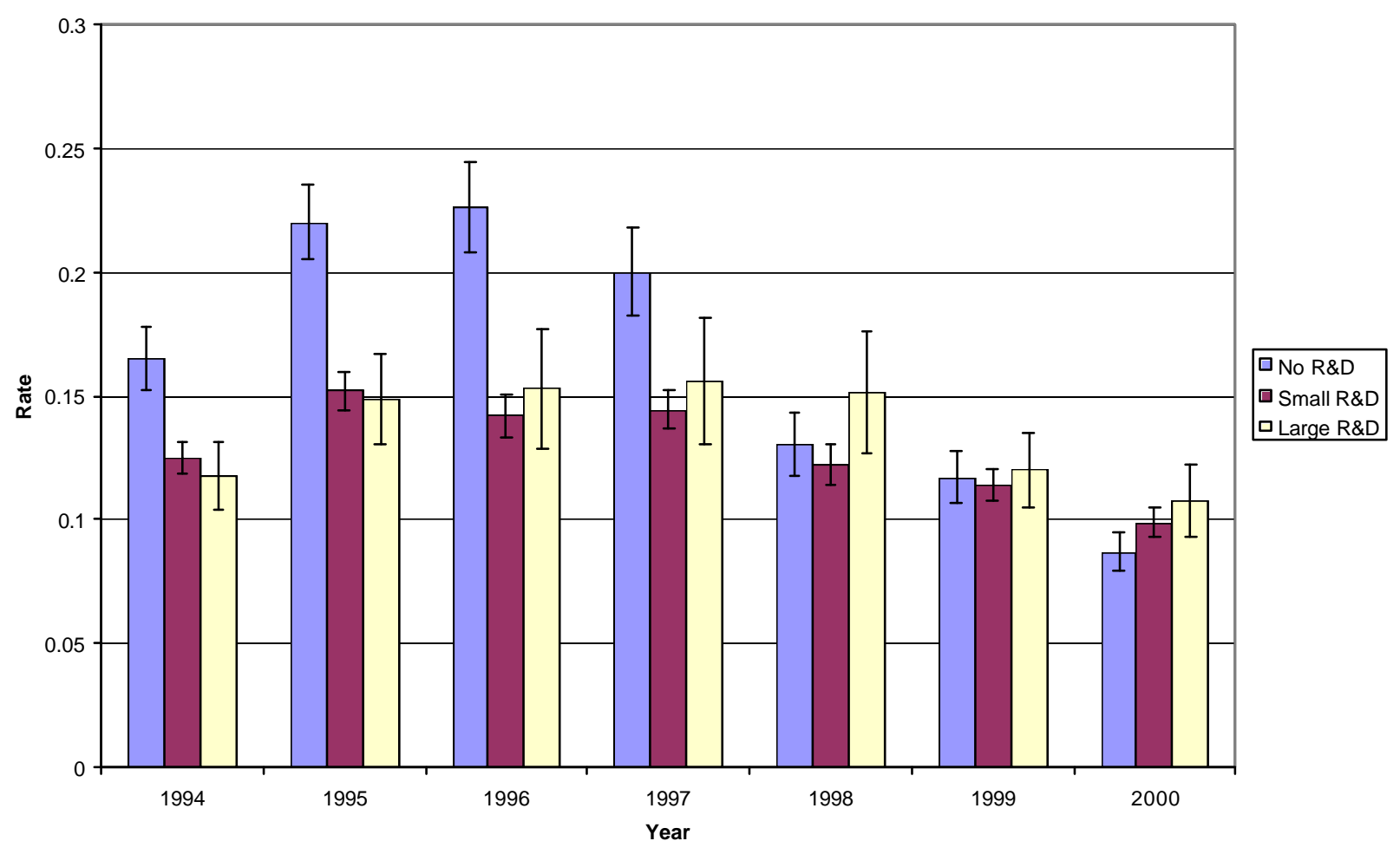




\section{IZA Discussion Papers}

\begin{tabular}{|c|c|c|c|c|}
\hline No. & Author(s) & Title & Area & Date \\
\hline 979 & $\begin{array}{l}\text { M. Moreno } \\
\text { H. Ñopo } \\
\text { J. Saavedra } \\
\text { M. Torero }\end{array}$ & $\begin{array}{l}\text { Gender and Racial Discrimination in Hiring: A } \\
\text { Pseudo Audit Study for Three Selected } \\
\text { Occupations in Metropolitan Lima }\end{array}$ & 1 & $01 / 04$ \\
\hline 980 & $\begin{array}{l}\text { H. Ñopo } \\
\text { J. Saavedra } \\
\text { M. Torero }\end{array}$ & Ethnicity and Earnings in Urban Peru & 1 & $01 / 04$ \\
\hline 981 & H. Ñopo & Matching as a Tool to Decompose Wage Gaps & 1 & $01 / 04$ \\
\hline 982 & $\begin{array}{l}\text { I. Geishecker } \\
\text { H. Görg }\end{array}$ & $\begin{array}{l}\text { Winners and Losers: Fragmentation, Trade and } \\
\text { Wages Revisited }\end{array}$ & 2 & $01 / 04$ \\
\hline 983 & $\begin{array}{l}\text { D. Del Boca } \\
\text { M. Locatelli } \\
\text { D. Vuri }\end{array}$ & Child Care Choices by Italian Households & 3 & $01 / 04$ \\
\hline 984 & $\begin{array}{l}\text { W. Arulampalam } \\
\text { A. L. Booth } \\
\text { M. L. Bryan }\end{array}$ & $\begin{array}{l}\text { Are there Asymmetries in the Effects of Training } \\
\text { on the Conditional Male Wage Distribution? }\end{array}$ & 5 & $01 / 04$ \\
\hline 985 & $\begin{array}{l}\text { Š. Jurajda } \\
\text { H. Harmgart }\end{array}$ & When Are 'Female' Occupations Paying More? & 4 & $01 / 04$ \\
\hline 986 & $\begin{array}{l}\text { H. Brücker } \\
\text { P. Trübswetter }\end{array}$ & $\begin{array}{l}\text { Do the Best Go West? An Analysis of the Self- } \\
\text { Selection of Employed East-West Migrants in } \\
\text { Germany }\end{array}$ & 1 & $01 / 04$ \\
\hline 987 & $\begin{array}{l}\text { A. Ichino } \\
\text { G. Muehlheusser }\end{array}$ & $\begin{array}{l}\text { How Often Should You Open the Door? Optimal } \\
\text { Monitoring to Screen Heterogeneous Agents }\end{array}$ & 7 & $01 / 04$ \\
\hline 988 & M. Jansen & Can Job Competition Prevent Hold-Ups? & 7 & $01 / 04$ \\
\hline 989 & J. Wagner & $\begin{array}{l}\text { Are Young and Small Firms Hothouses for } \\
\text { Nascent Entrepreneurs? Evidence from German } \\
\text { Micro Data }\end{array}$ & 1 & $01 / 04$ \\
\hline 990 & $\begin{array}{l}\text { H. Bonin } \\
\text { C. Patxot }\end{array}$ & $\begin{array}{l}\text { Generational Accounting as a Tool to Assess } \\
\text { Fiscal Sustainability: An Overview of the } \\
\text { Methodology }\end{array}$ & 7 & $01 / 04$ \\
\hline 991 & S. Verick & $\begin{array}{l}\text { Threshold Effects of Dismissal Protection } \\
\text { Legislation in Germany }\end{array}$ & 1 & $01 / 04$ \\
\hline 992 & A. Heitmueller & $\begin{array}{l}\text { Public-Private Sector Wage Differentials in } \\
\text { Scotland: An Endogenous Switching Model }\end{array}$ & 7 & $01 / 04$ \\
\hline 993 & $\begin{array}{l}\text { A. Calderon-Madrid } \\
\text { A. Voicu }\end{array}$ & $\begin{array}{l}\text { Total Factor Productivity Growth and Job } \\
\text { Turnover in Mexican Manufacturing Plants in the } \\
\text { 1990s }\end{array}$ & 4 & $01 / 04$ \\
\hline
\end{tabular}

An updated list of IZA Discussion Papers is available on the center's homepage www.iza.org. 